\title{
Education, Complaints, and Accountability
}

\author{
Juan Botero World Justice Project \\ Alejandro Ponce World Justice Project \\ Andrei Shleifer Harvard University
}

\begin{abstract}
Better-educated countries have better governments, an empirical regularity that holds in both dictatorships and democracies. Possible reasons for this fact are that educated people are more likely to complain about misconduct by government officials and that more frequent complaints encourage better behavior from officials. Newly assembled individual-level survey data from the World Justice Project show that, within countries, better-educated people are more likely to report official misconduct. The results are confirmed using other survey data on reporting crime and corruption. Citizens' complaints might thus be an operative mechanism that explains the link between education and the quality of government.
\end{abstract}

\section{Introduction}

By just about any measure, the quality of government is higher in richer and more educated countries. Such countries tend to be more democratic, politically freer, more respectful of property rights, less corrupt, and more efficient in the provision of public services such as infrastructure and regulation (see, for example, La Porta et al. 1999; Barro 1999; Treisman 2000; Svensson 2005). Figures 1-4 illustrate some well-known correlations between education and the quality of government. The positive correlation between education (or per capita in-

A previous version of this paper circulated under the title "Education and the Quality of Government." We are grateful to Ernesto Dal Bó, Larry Katz, Sendhil Mullainathan, Emily Oster, Benjamin Schoefer, Josh Schwartzstein, Jesse Shapiro, Daniel Treisman, the referees, and the editor for helpful comments. We thank Transparency International for sharing the Global Corruption Barometer 2009 data. Botero and Ponce thank the Bill and Melinda Gates Foundation and the Ewing Marion Kauffman Foundation for their support of the World Justice Project. Shleifer thanks the Kauffman Foundation for the support of his research. The views expressed in this paper are those of the authors and do not necessarily represent the views of the World Justice Project, its board of directors, or its honorary chairs.

[Journal of Law and Economics, vol. 56 (November 2013)]

(C) 2013 by The University of Chicago. All rights reserved. 0022-2186/2013/5604-0028 $\$ 10.00$ 


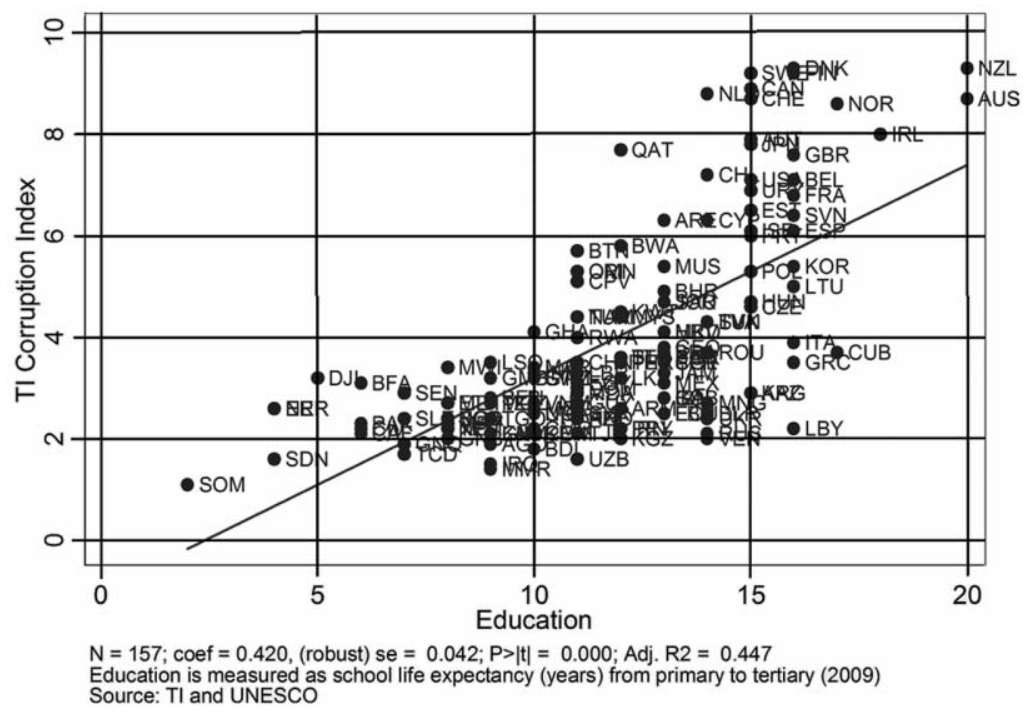

Figure 1. The quality of government and education: Transparency International's Corruption Perceptions Index.

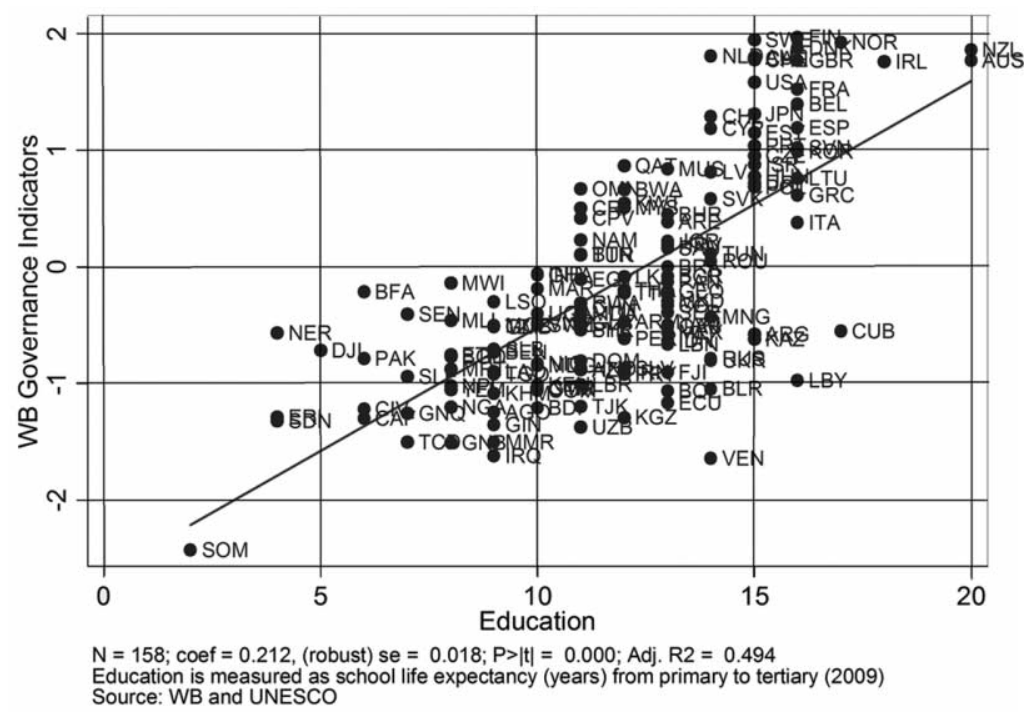

Figure 2. The quality of government and education: World Bank's Worldwide Governance Indicators. 


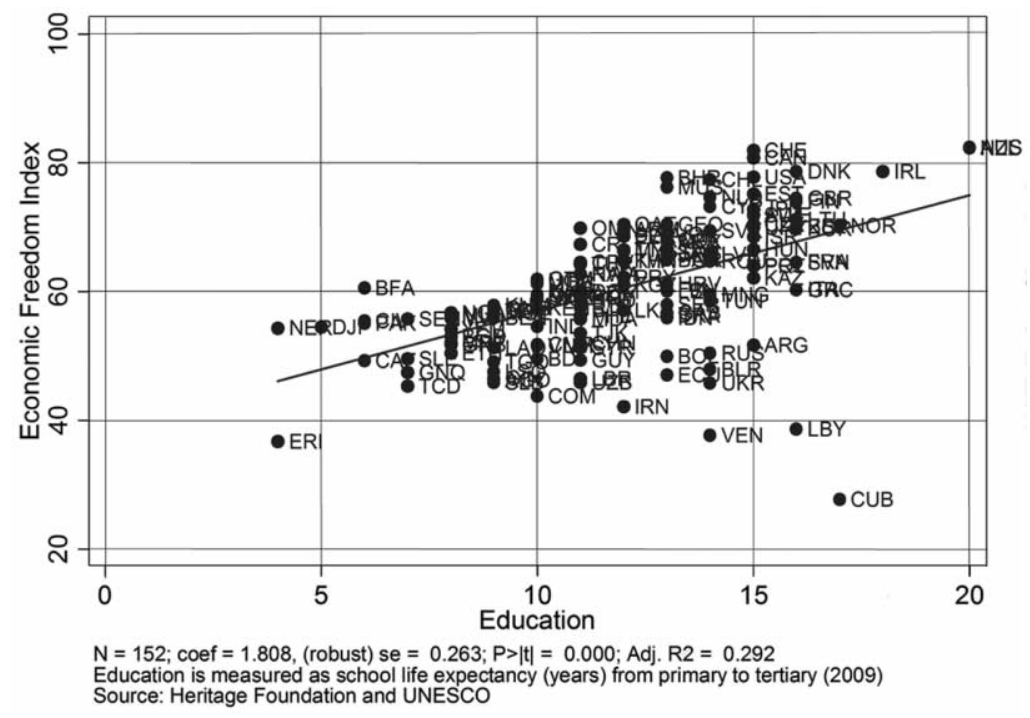

Figure 3. The quality of government and education: Heritage Foundation's Economic Freedom Index.

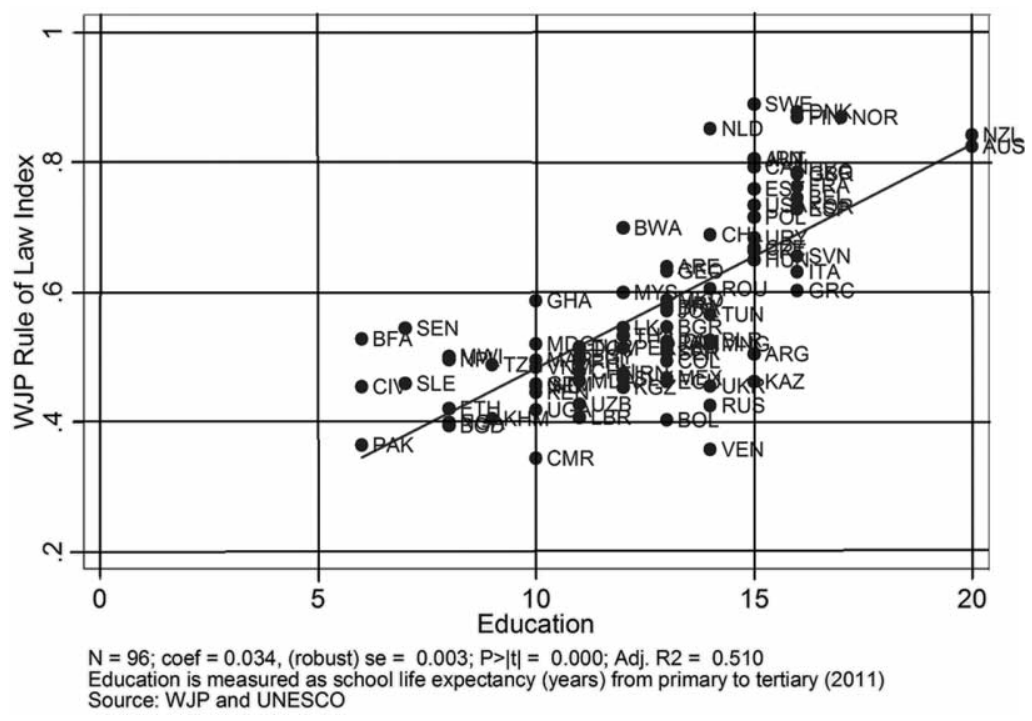

Figure 4. The quality of government and education: World Justice Project's Rule of Law Index. 
come) and the quality of government holds in both dictatorships and democracies (Figures 5-8). It also holds in countries with different legal traditions, ethnic heterogeneity, and inequality (La Porta et al. 1999). Most studies find that education and development lead to improved government (for example, see Barro 1999; Glaeser et al. 2004; Bobba and Coviello 2007; Castello-Climent 2008; Murtin and Wacziarg 2011), although some disagree (Acemoglu et al. 2005). In this paper, we ask why the quality of government improves with education and development, assuming that it does.

The most common explanation for the improvement in the quality of government in the process of development is accountability. Perhaps the central mechanism of such accountability, going back at least to Hirschman's (1970) idea of voice, is voting. If voters punish incompetent or corrupt politicians, and if education promotes political participation and voting, then increases in education lead to improvements in the quality of government. Verba and Nie (1972) and Verba, Schlozman, and Brady (1995) are among the first prominent studies in political science that link education to political participation. These studies consider both voting and other forms of participation, such as volunteering. Dee (2004) and Milligan, Moretti, and Oreopoulus (2004) provide evidence of causal links between education and voting.

Voting is surely important, but the fact that the quality of government improves with education in dictatorships as well as in democracies is an indication that voting is not the only mechanism linking the two. In fact, recent research has broadened the notions of political accountability and focused on the roles of audits, the media, disclosure by politicians, political checks and balances, and even uprisings in monitoring government misconduct. Some of the growing number of studies in this area include Reinikka and Svensson $(2004,2005)$, Glaeser, Ponzetto, and Shleifer (2007), Olken (2007), Pandey et al. (2007), Ferraz and Finan (2008, 2011), Djankov et al. (2010), Pande (2011), and Ferraz, Finan, and Moreira (2012).

In this paper, we propose a complementary mechanism of accountability. In our view, one reason why government improves is that citizens complain about public officials who mistreat them: policemen who beat them up, officials who demand bribes, teachers who do not show up. All countries have some laws against police abuse, corruption, and public employee absenteeism, which include penalties for official misconduct. A public official choosing to break rules must trade off the risk of being disciplined, no matter how small for each individual complaint, against the benefits of misconduct. As citizens' complaints proliferate, the risk of an investigation and disciplinary action rises. We propose that educated people are more likely to complain about official misconduct (and perhaps to complain more effectively). As education levels in a country rise, so does the number of complaints when officials misbehave, which raises the expected costs of misconduct and thus encourages better behavior-asking for fewer bribes, avoiding abusing people, showing up to work. Through this entirely decentralized process, only roughly dependent on the prevailing political arrangements such 


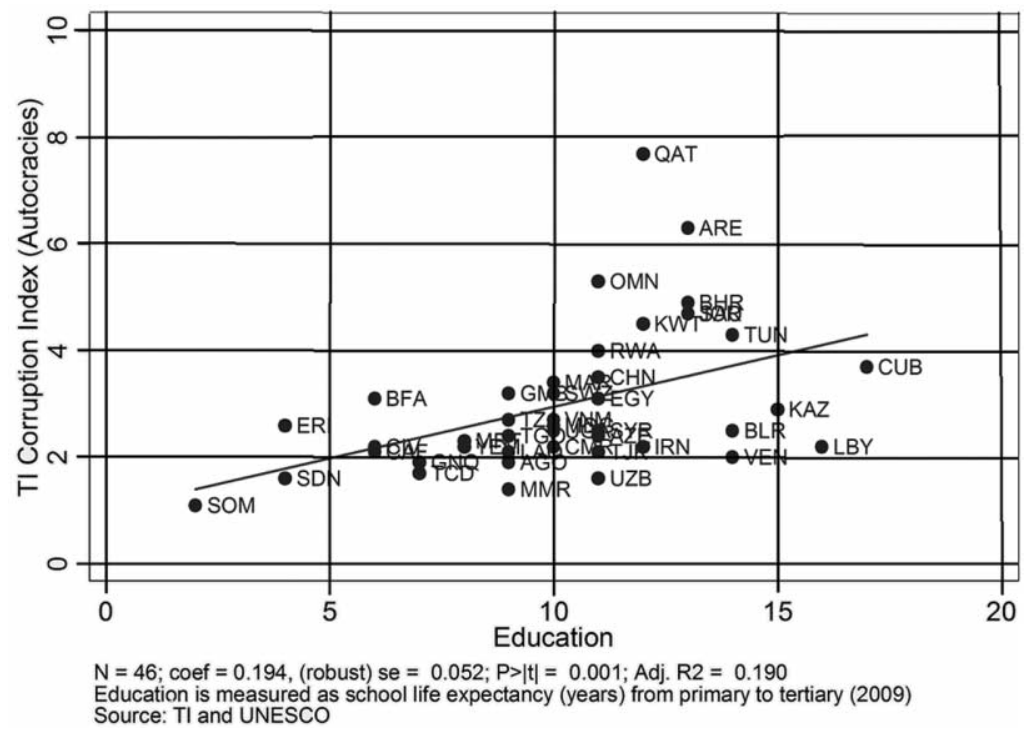

Figure 5. The quality of government and education in autocratic regimes: Transparency International's Corruption Perceptions Index.

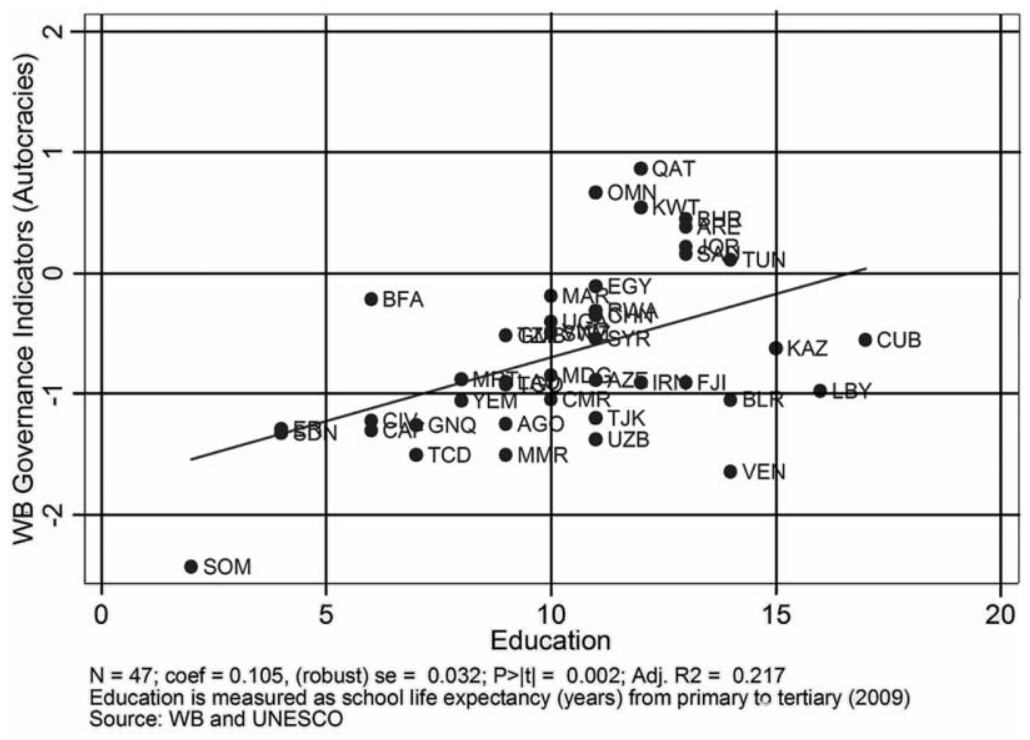

Figure 6. The quality of government and education in autocratic regimes: World Bank's Worldwide Governance Indicators. 


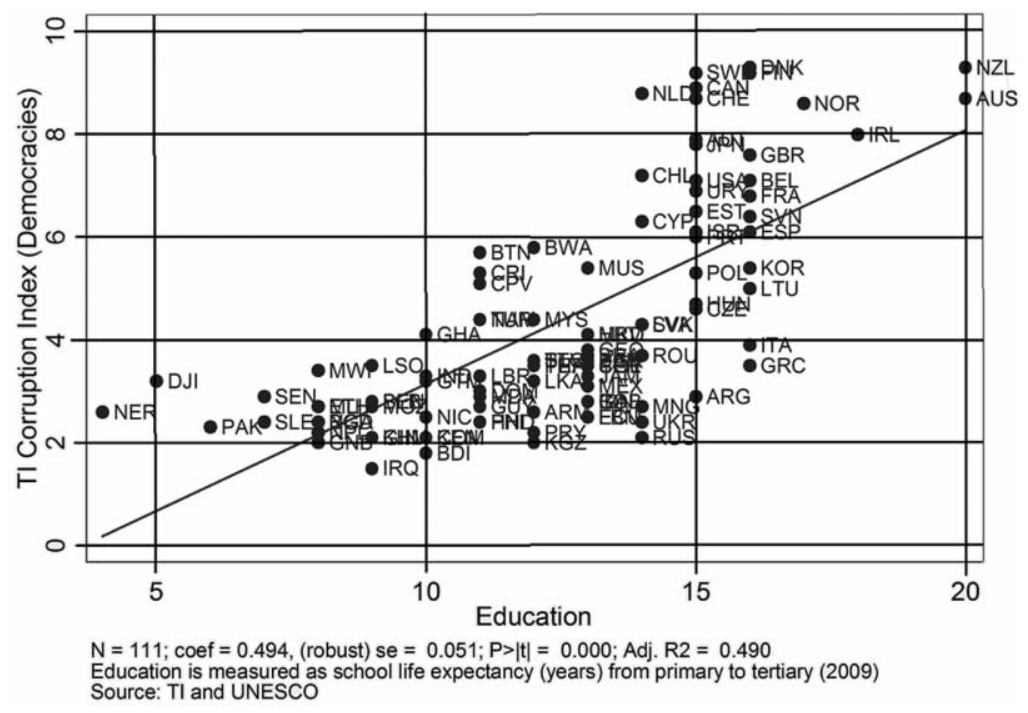

Figure 7. The quality of government and education in democratic regimes: Transparency International's Corruption Perceptions Index.

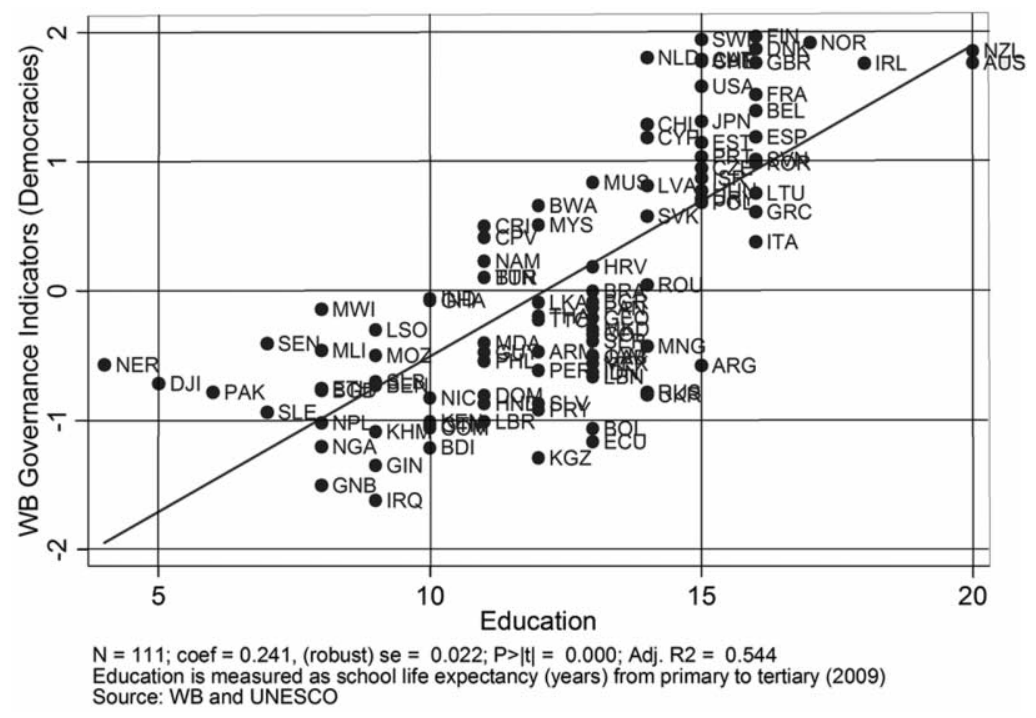

Figure 8. The quality of government and education in democratic regimes: World Bank's Worldwide Governance Indicators. 
as democracy or dictatorship, the quality of government improves. Botero, Ponce, and Shleifer (2012) presents a simple model illustrating this mechanism.

We present evidence bearing on three hypotheses derived from this view of complaints and accountability: educated people complain more, citizens complain more in countries with a higher probability of action being taken against a misbehaving official, and better-educated countries have a lower incidence of public misconduct. Our main data source is a series of surveys of the general population carried out by the World Justice Project (WJP) in 97 countries between 2009 and 2012 (Agrast et al. 2012). These surveys cover the experiences and perceptions of people in their dealings with the government, the police, and the courts, as well as with crime and victimization. The data also contain information about the demographic characteristics of the respondents, including their education.

The principal questions from the WJP surveys that we examine deal with official misconduct and whether it was reported by the victim. There are two main questions in the surveys: the first asks whether respondents have complained about some aspect of government services in general during the previous year. The second question asks whether respondents experienced police abuse and, if so, whether they reported it. In addition, the WJP surveys contain information about respondents reporting crime, specifically break-ins and armed robberies. ${ }^{1}$ Although these questions do not pertain to complaints about public misconduct per se, they do give us information about the propensity to report problems to the government and thus shed light on the relationship between education and voice. Finally, the surveys ask respondents to assess whether policemen who violate the law will be punished, and we use these data as a proxy for the expected likelihood of the success of a complaint.

To further check the robustness of our results, we supplement WJP data with some questions from the International Crime Victims Survey (ICVS), which contains information about households' experiences with crime, including reporting to the police, for thousands of respondents in 78 countries. The ICVS contains a number of questions concerning the reporting of crime, which enables us to assess the robustness of our WJP findings on reporting using different data. In addition, for a few questions, the ICVS asks the respondents the reasons for reporting or not reporting the incidents of crime and corruption. We also use the Global Corruption Barometer from Transparency International (TI) to examine the incidence of corruption in a number of countries, whether it is reported, and the reasons for reporting or not reporting.

Our main findings can be easily summarized. First, we find empirical support for the proposition that, within countries, people who are more educated complain more about both government misconduct when it occurs and crime in general. This relationship is particularly strong in developing countries, consistent

\footnotetext{
${ }^{1}$ The relationship between education and crime reporting has been studied by Soares (2004a, 2004b) and Di Tella, Edwards, and Schargrodsky (2010) in a different context.
} 
with the view that, in developed countries, even the less educated have the knowledge and lack of fear to complain. Second, the country-average assessment that a policeman violating the law will be punished is a strong predictor of the probability of complaining about misconduct and reporting crime. Third, the results are particularly strong in autocracies, which suggests that voting might not be the only important exercise of voice in the political process. Fourth, the analysis of additional data sets confirms our main findings. Fifth, educated countries have a lower incidence of public and private misconduct. Overall, the evidence is consistent with the view that complaints influence accountability.

In our regressions, education may proxy for something else, such as income, trust, social status, or even gender. For example, richer people might be able to hire lawyers, or even to find time, to make their complaints more effective (on the other hand, their time is more valuable, so they might not bother). Wolfinger and Rosenstone (1980) show empirically, however, that education is more important than income as a determinant of political participation. One can likewise argue that trust in institutions is correlated with education and that trust rather than education drives complaints. It could also be that socioeconomic status or gender drives confidence in the success of a complaint and hence the likelihood that it is made.

We examine all these alternatives empirically. The evidence shows that few of these factors influence the likelihood of complaining, and none eliminate the large impact of education on complaints. While it is still possible that education is correlated with a relevant omitted individual-specific variable, such as personal drive or ambition, there is some reason to believe that education is indeed an important determinant in individuals' decisions to report government misconduct. Our analysis is of course based on cross-sectional data and as such does not prove causation. It nonetheless identifies an interesting relationship that deserves further exploration.

The empirical analysis raises a number of questions of interpretation. First, why are the more educated more likely to complain? There are at least three possibilities. First, educated people might merely know better how to complain effectively: they are more literate, more articulate, and more knowledgeable about where to go and how to complain. This is a pure human capital channel: complaining is like any other activity for which productivity rises with education. Verba and Nie (1972), Verba, Scholzman, and Berry (1995), and Nie, Junn, and Stehlik-Berry (1996) take this point of view with respect to political participation. A second channel is that educated people are more prosocial, share common values, and are less tolerant of injustice (Dewey 1944; Hayek 1960; Putnam 1993; Campbell 2006; Glaeser, Ponzetto, and Shleifer 2007; Algan, Cahuc, and Shleifer 2013). Because better-educated people are better socialized, they are more willing to complain about public misconduct even when the odds of private success are low. A third channel, intimately related to the first, sees educated people as less fearful of official reprisals. This might be in part because they know the law and the rules and hence can stand up to officials, but it might also be because they 
are themselves legal—work formally, occupy their residence formally—and hence do not feel at risk. We explore some of these possibilities empirically and find that fear of police reprisals and the lack of knowledge of how to complain seem to be important factors behind silence.

In Section 2, we describe our data. Section 3 presents the basic findings from the WJP database. Section 4 examines other data sources. Section 5 concludes. Our findings are broadly consistent with the hypothesis that, via the complaint mechanism, education promotes government accountability and ultimately the quality of institutions.

\section{Data}

The arguments outlined above yield three main hypotheses: educated people are more likely to complain within a country, a higher expected probability of success in a country encourages complaints, and more educated countries have a lower incidence of public misconduct, in equilibrium. We bring these hypotheses to the data using individual-level data on citizens' complaints and reporting from the general population polls of the WJP (Agrast et al. 2012). Over the last 3 years, the WJP has conducted extensive surveys in 97 countries of the perceptions and experiences of ordinary people concerning their dealings with the government, the police, and the courts; the extent of corruption; and the magnitude of common crimes to which the general public is exposed. These surveys were carried out in three waves in 2009, 2011, and 2012 on probability samples of 1,000 respondents drawn from the three largest cities in each country and were conducted by professional polling organizations using face-to-face, telephone, and online interviews. All survey questions we use deal with personal experiences of individuals or their families. Our final sample contains data for 88 countries. These are the countries for which information on the level of education status of respondents was available (online Appendix A presents the list of countries covered by the WJP that have information available on the level of education of respondents). ${ }^{2}$

Our basic measures of citizens' complaints about public officials come from two questions. The first question, available only in the 2011 and 2012 waves of data collection, is worded as follows: "During the last year, did you submit any complaint about the services provided by the different government agencies in your country (including registration office; customs office; public health services; tax office; land allocation office, etc.)?" The second question asks whether respondents experienced police abuse and, if so, whether they reported it. The question reads, "In the last 3 years, have you or someone in your household,

\footnotetext{
${ }^{2}$ The distribution of countries in the sample is 14 from sub-Saharan Africa, six from the Middle East and North Africa, five from South Asia, 19 from Eastern Europe and central Asia, 13 from East Asia and Pacific, 15 from Latin America and the Caribbean, and 16 from Western Europe and North America.
} 
been subjected to physical abuse by the police or the military?" It is followed by the question "Did you or anyone else report the crime to the police or other authority?"

The WJP polls also ask respondents whether they were the victim of a crime during the last 3 years and whether they reported it to the police. We use two of these questions. The first question asks, "In the past 3 years, did anyone actually break into your home/residence without permission, and steal or try to steal something?" and "Did you or anyone else report the crime to the police?" The second question asks, "In the past 3 years, were you a victim of an armed robbery (with a weapon such as a knife or a gun)?" and "Did you or anyone else report the crime to the police?" The latter question was asked only in the 2011 and 2012 waves of data collection.

The WJP data also contain demographic information, particularly on education, but also on income, trust, gender, and asset ownership, which can be converted into indicators of socioeconomic status. We construct two indicators of education level: college and high/middle school. The first indicator equals one if the respondent answered "bachelor's degree" or "graduate degree (master's, Ph.D.)" to the question "What is the highest degree you received?" The second indicator is coded one if the respondent answered, "middle school diploma" or "high school diploma or equivalent."

A key determinant of complaining about government misconduct is the estimated probability of success. Using WJP data, we construct a country-level proxy for this probability, based on a qualitative assessment of the following question: "In [country], if members of the police violate the law, they are punished for these violations." Because, unlike our data on complaints and reporting, this question does not deal with a personal experience, we use country averages.

We supplement the WJP data with information from the ICVS and the 2009 TI Global Corruption Barometer. The ICVS is an international poll designed to provide comparable data on people's recent experience with common crime around the world. By 2005, over 140 surveys had been completed in 75 different countries, totaling over 320,000 individual respondents. We construct a sample using the most recent data for each country and focus on two groups of questions. The first group asks respondents whether they have experienced burglary, attempted burglary, robbery, fraud, or personal theft and whether the crime was reported to the police. The second group asks whether respondents have been solicited for bribes in the previous year and whether they reported the incident, as well as the reasons for reporting or not reporting it. The ICVS includes demographic characteristics, but questions regarding respondents' level of education are not consistently asked throughout the different waves of data collection. Accordingly, we define college by the highest degree attained, the years of schooling (more than 15), or whether the respondent completed school when he or she was older than 21 . Similarly, we define high/middle school as having finished middle or high school, having between 9 and 15 years of schooling, or having completed school when the respondent was between 15 and 21 years old. 
The TI Global Corruption Barometer is a worldwide public opinion survey on the general public's views and experiences of corruption. Each country sample is probabilistic and is weighted to provide a representative sample of the national population. We use three questions from the 2009 wave, which covers 69 countries: "Over the past 12 months, have you or anyone living in your household paid a bribe in any form?" and the follow-up questions "Did you present a formal complaint in this regard?" and "Why you did not present the complaint?"

Table 1 presents the definitions of the variables from the WJP and the supplementary sources used in the analysis, and online Appendix B displays the summary statistics for our main variables. As online Appendix B shows, there is a fair amount of variation in the level of education and the probability of complaining among countries. For instance, the fraction of college graduates in the three largest cities covered in our data ranges from 4 percent in Sri Lanka to 71 percent in Russia, while the proportion of people who submitted a complaint about a government agency goes from 2 percent in Georgia to 38 percent in Ethiopia.

\section{Evidence}

\subsection{Basic Findings}

To begin, we focus on the relationship between education and the reporting of government misconduct or crime at the individual level. Our basic specification includes two indicator variables for whether the respondent is a college graduate or a high school graduate and country fixed effects to control for potential country-specific omitted variables. The dependent variables are dummies equal to zero or one depending on whether a particular event occurred. Unless otherwise noted, all the results are estimated using ordinary least squares with country fixed effects and standard errors clustered at the country level so as to account for dependence among observations within each country. This specification allows us to examine most simply the extent to which respondents' reporting behavior is related to their education, other observable characteristics, and their country's institutional environment.

Table 2 contains results for seven questions from the WJP database. Four of these questions were administered in 88 countries, for a total of about 87,000 observations. ${ }^{3}$ The remaining questions were asked in only 63 countries. The first three questions deal with reporting government misconduct; the last four questions deal with reporting crime. For each individual in the survey, we have data on whether he or she is a college graduate, is a high school graduate, or has less than a high school education.

The first question asks whether the respondent submitted a complaint about

\footnotetext{
${ }^{3}$ The questions on police abuse victimization and burglary victimization contain 86,528 and 86,678 observations, respectively. The follow-up questions were asked only of respondents who said they had been victimized, for a total of 5,005 and 11,663 observations, respectively.
} 
Table 1

Description of the Variables

\section{Variable} Description

Cross-country variables:

Education ${ }^{2}$

Transparency International (TI) Corruption Perceptions Index ${ }^{\mathrm{b}}$

World Bank Governance Indicators

Heritage Economic Freedom Index ${ }^{\mathrm{d}}$
The expected number of years of schooling, or school life expectancy (SLE); it is defined as the total number of years of schooling that a child can expect to receive, assuming that the probability of his or her being enrolled in school at any particular future age is equal to the current enrollment ratio at that age; it is a synthetic summary indicator of the overall pattern of enrollment ratios at one particular point in time and has no predictive value except in so far as it is believed that enrollment patterns will remain unchanged into the future

The score of the Corruption Perceptions Index 2010; the index provides a measure of the extent to which corruption is perceived to exist in the public and political sectors; the index focuses on corruption in the public sector and defines corruption as the abuse of public office for private gain; the index ranges between 0 (highly corrupt) and 10 (highly clean)

The averaged score of the Worldwide Governance Indicators 2010 (WGI); the WGI 2010 reports aggregate and

individual governance indicators for 213 economies for six dimensions of governance: voice and accountability, political stability and absence of violence, government effectiveness, regulatory quality, rule of law, and control of corruption

The score of the Heritage Foundation Index of Economic Freedom in 2011; the index measures 10 components of economic freedom, assigning a grade in each using a scale from 0 to 100 , where 100 represents the maximum freedom; the 10 components of economic freedom are business freedom, trade freedom, fiscal freedom, government spending, monetary freedom, investment freedom, financial freedom, property rights, freedom from corruption, and labor freedom 
WJP Rule of Law Index

Democracy $^{\mathrm{f}}$

Autocracy ${ }^{f}$

Educated $^{a}$

Log GNI per Capita

Punishment for Police Misconduct (country average $)^{\mathrm{h}}$

Within-country variables: World Justice Project: $^{\text {h }}$

\section{High/Middle School (WJP)}

Complained about Government Services

Police Abuse

\section{Report Police Abuse}

Burglary (WJP)

Report Burglary (WJP)

Assault

The average of the eight factors of the Rule of Law Index measured in 2011: limited government powers, corruption, order and security, fundamental rights, open government, effective regulatory enforcement, access to civil justice, and effective criminal justice; scores range between 0 and 1, with 1 representing a higher adherence to the rule of law Indicator variable coded one if the polity 2 score from the 2011 Polity IV data set is below 0; the polity2 score is computed by subtracting a county's autocracy score from its democracy score; the resulting unified polity scale ranges from +10 (strongly democratic) to -10 (strongly autocratic)

Indicator variable coded one if the polity2 score from the 2011 Polity IV data set is equal to or larger than 0 Indicator variable coded one if the SLE in the country is greater than 14 years

The natural logarithm of the gross national income (GNI) per capita (formerly GNP per capita) for the year 2011 calculated as the gross national income converted to U.S. dollars using the World Bank Atlas method and divided by the midyear population

Country average of a categorical variable coded $1, .66, .33$, or 0 if the respondent answered, respectively, "always," "often," "rarely," or "never" to the question "In [COUNTRY], if members of the police violate the law, they are punished for these violations"

Indicator variable coded one if the respondent answered "bachelor's degree" or "graduate degree (master's, Ph.D.)" to the question "What is the highest degree you received?"

Indicator variable coded one if the respondent answered "middle school diploma" or "high school diploma or equivalent" to the question "What is the highest degree you received?"

Indicator variable coded one if the respondent answered "yes" to the question "During the last year, did you submit any complaint about the services provided by the different government agencies in your country (including registration office; customs office; public health services; tax office; land allocation office, etc.)?"

Indicator variable coded one if the respondent answered "yes" to the question "In the last 3 years, have you or someone in your household, been subjected to physical abuse by the police or the military?"

Indicator variable coded one if the respondent answered "yes" to the question (for those who have been victimized) "Was the crime reported to the police or other authority?"

Indicator variable coded one if the respondent answered "yes" to the question "In the past 3 YEARS, did anyone actually BREAK into your home/residence without permission, and steal or try to steal something?"

Indicator variable coded one if the respondent answered "yes" to the question (for those who answered Yes to Burglary) "Did you or anyone else report the crime to the police?"

Indicator variable coded one if the respondent answered "yes" to the question "In the past 3 YEARS, were you a victim of an ARMED ROBBERY (with a weapon such as a knife or a gun)?" 
Table 1 (Continued)

Variable

Description

Report Assault

Trust Index

Trust in Others

Wealth: Asset

Within-country variables:

International Crime Victim

Survey: ${ }^{i}$

College (ICVS)

High/Middle School (ICVS)

Burglary (ICVS)

Report Burglary (ICVS)

Attempt
Indicator variable coded one if the respondent answered "yes" to the question (for those who answered Yes to Assault) "Did you or anyone else report the crime to the police?"

Index between 0 and 1 , where 1 indicates more trust and is the average of four questions: How much TRUST do you have in each of the following categories of people, groups of people, and institutions? (1) Officers working in the local government; (2) officers working in the national government; (3) the police; (4) the courts (on a 4-point scale from 0 [no trust] to 1 [a lot of trust])

Categorical response to the following question: How much TRUST do you have in each of the following categories of people, groups of people, and institutions? People living in this country (on a 4-point scale from 0 [no trust] to 1 [a lot of trust])

Indicator variable coded one if the respondent/household has the asset, service, or utility service described in the question

Indicator variable equal to one if the respondent answered "high/university" to the question "How would you define your level of education?" (43 countries in our sample) or if the respondent reported having more than 15 years of formal education ( 24 countries in our sample) or if the respondent had completed school when he or she was older than 21 years (eight countries in our sample)

Indicator variable equal to one if the respondent answered "secondary" or "college" to the question "How would you define your level of education?" (43 countries in our sample) or if the respondent reported having between 9 and 15 years of formal education (24 countries in our sample) or if the respondent had completed school when he or she was between 15 and 21 years old (eight countries in our sample)

Indicator variable coded one if the respondent answered "yes" to the question "Over the past five years, did anyone actually get into your home/residence without permission, and steal or try to steal something? I am not including here thefts from garages, sheds or lock-ups"

Indicator variable coded one if the respondent answered "yes" to the question "Did you or anyone else report the last burglary/housebreaking to the police?"

Indicator variable coded one if the respondent answered "yes" to the question "Apart from this, over the past five years, do you have any evidence that someone tried to get into your home/residence unsuccessfully. For example, damage to locks, doors or windows or scratches around the lock?" 
Report Attempt

Robbery

Report Robbery

Fraud

Report Fraud

Theft

ֻै Report Theft

Corruption (ICVS)

Report Corruption Police (ICVS

Report Corruption Other (ICVS)

Reasons for Not Reporting (ICVS)

Reasons for Reporting (ICVS)
Indicator variable coded one if the respondent answered "yes" to the question "[The last time this happened] did you or anyone else report the attempted burglary/housebreaking to the police?"

Indicator variable coded one if the respondent answered "yes" to the question "Over the past five years has anyone stolen something from you by using force or threatening you, or did anybody try to steal something from you by using force or threatening force?"

Indicator variable coded one if the respondent answered "yes" to the question "[The last time this happened] did you or anyone else report the robbery to the police?"

Indicator variable coded one if the respondent answered "yes" to the question "Last year, in 2004 were you the victim of a consumer fraud. In other words, has someone-when selling something to you or delivering a service—cheated you in terms of quantity or quality of the goods or services?"

Indicator variable coded one if the respondent answered "yes" to the question "[The last time this happened] did you or anyone else report the robbery to the police?"

Indicator variable coded one if the respondent answered "yes" to the question "Apart from theft involving force there are many other types of theft of personal property, such as pick-pocketing or theft of a purse, wallet, clothing, jewelry, sports equipment. This can happen at one's work, at school, in a pub, on public transport, on the beach, or in the street. Over the past five years have you personally been the victim of any of these thefts?"

Indicator variable coded one if the respondent answered "yes" to the question "[The last time this happened] did you or anyone else report the robbery to the police?"

Indicator variable coded one if the respondent answered "yes" to the question "During 2004, has any government official, for instance a customs officer, a police officer or inspector in your country asked you, or expected you to pay a bribe for his or her services?

Indicator variable coded one if the respondent answered "yes" to the question "[The last time] did you or anyone else report this problem of corruption to the police?"

Indicator variable coded one if the respondent answered "yes" to the question "[The last time] did you or anyone else report it to any public or private agency?"

ndicator variables coded one if the respondent answered "yes" to the options of the question "If not, why didn't you report it?" (A) not serious enough; (B) solved it myself; (C) inappropriate for police; (D) other authorities; (E) my family solved it; (F) no insurance; (G) police could do nothing; (H) police won't do anything; (I) fear/dislike of police; $(\mathrm{J})$ did not dare; $(\mathrm{K})$ other reasons

Indicator variables coded one if the respondent answered "yes" to the options of the question "If yes, why did you report it?" (A) recover property; (B) insurance reasons; (C) should be reported; (D) want offender caught; (E) to stop it; (F) to get help; $(\mathrm{G})$ compensation; $(\mathrm{H})$ other reasons 
Table 1 (Continued)

Within-country variables: Global

Corruption Barometer:

College (Barometer)

High/Middle School (Barometer) Indicator variable coded one if the respondent answered "secondary school" to the question "What is the highest

Indicator variable coded one if the respondent answered "high level education (for example, university)" to the question "What is the highest education attained?" education attined?"

Corruption (Barometer)

Report Corruption (Barometer)

Indicator variable coded one if the respondent answered "yes" to the question "In the past 12 months, have you or anyone living in your household paid a bribe in any form?"

- variable coded one if the respondent answered "yes" to the question "If in the past 12 months you or any

member of your household were asked to pay a bribe to obtain a service or to resolve a problem, did you present a formal complaint in this regard?"

Reasons for Not Reporting

(Barometer)

Indicator variables coded one if the respondent answered "yes" to the options of the question "Why you did not present the complaint?" (A) Did not know how to do it; (B) it would have taken too much time; (C) it would not have helped at all; (D) tried but couldn't; (E) fear of reprisals; (F) other reasons

${ }^{a}$ United Nations Statistics Division, Social Indicators (http://unstats.un.org/unsd/demographic/products/socind/).

Transparency International, Corruption Perceptions Index 2010 (http://www.transparency.org/cpi2010).

World Bank, Worldwide Governance Indicators (http://info.worldbank.org/governance/wgi/index.aspx\#home).

Heritage Foundation, Explore the Data (http://www.heritage.org/index/explore).

World Justice Project, The Rule of Law Index (http://www.worldjusticproject.org/rule-of-law-index).

Center for Systemic Peace, Polity 4 Project (http://www.systemicpeace.org/polity/polity4.htm)

The

(2011).

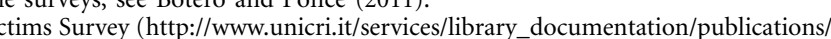
icvs/).

Transparency International, Global Corruption Barometer 2009 (http://www.transparency.org/research/gcb/gcb_2009). 
Table 2

Complaints and Education: World Justice Project (WJP)

\begin{tabular}{|c|c|c|c|c|c|c|c|}
\hline & $\begin{array}{c}\text { Complained } \\
\text { about } \\
\text { Government } \\
\text { Services }\end{array}$ & $\begin{array}{l}\text { Police } \\
\text { Abuse }\end{array}$ & $\begin{array}{l}\text { Report } \\
\text { Police } \\
\text { Abuse }\end{array}$ & $\begin{array}{c}\text { Burglary } \\
\text { (WJP) }\end{array}$ & $\begin{array}{c}\text { Report } \\
\text { Burglary } \\
\text { (WJP) }\end{array}$ & Assault & $\begin{array}{l}\text { Report } \\
\text { Assault }\end{array}$ \\
\hline College (WJP) & $\begin{array}{l}.051^{* *} \\
(.010)\end{array}$ & $\begin{array}{l}-.006 \\
(.004)\end{array}$ & $\begin{array}{l}.080^{\star} \\
(.031)\end{array}$ & $\begin{array}{l}.027^{\star *} \\
(.006)\end{array}$ & $\begin{array}{l}.102^{\star *} \\
(.018)\end{array}$ & $\begin{array}{l}.023^{\star *} \\
(.008)\end{array}$ & $\begin{array}{l}.088^{\star *} \\
(.022)\end{array}$ \\
\hline High/Middle School (WJP) & $\begin{array}{l}.028^{* *} \\
(.009)\end{array}$ & $\begin{array}{c}-.007^{+} \\
(.004)\end{array}$ & $\begin{array}{l}.031 \\
(.028)\end{array}$ & $\begin{array}{l}.010^{+} \\
(.005)\end{array}$ & $\begin{array}{l}.052^{\star *} \\
(.014)\end{array}$ & $\begin{array}{l}.016^{*} \\
(.006)\end{array}$ & $\begin{array}{l}.01 \\
(.017)\end{array}$ \\
\hline$N$ & 60,634 & 86,528 & 5,005 & 86,678 & 11,663 & 61,812 & 4,090 \\
\hline$R^{2}$ & .108 & .074 & 142 & .057 & .176 & .102 & .159 \\
\hline Countries & 63 & 88 & 88 & 88 & 88 & 63 & 63 \\
\hline Mean dependent variable & 156 & .0603 & 468 & 136 & 611 & .0665 & .599 \\
\hline
\end{tabular}

Note. Values are the results of ordinary least squares regressions of the dependent variables from the WJP data set on indicator variables for the education status of the respondents. All regressions include fixed effects for countries. Clustered standard errors are in parentheses.

+ $p<.1$.

${ }^{*} p<.05$.
${ }^{* *} p<.01$. 
services provided by any government agency during the past year. Compared with individuals with less than a high school degree, college graduates are 5.1 percentage points more likely to have submitted a complaint $(t=5.19)$, while high school graduates are 2.8 percentage points more likely to have submitted a complaint $(t=3.08)$. These are large effects compared with the worldwide mean for complaining of 15.6 percent. The second question asks whether the respondent or someone in his or her household has been unfairly subjected to physical abuse by the police or the military during the last 3 years. College and high school graduates are less likely to say that they have been abused, but these effects are not statistically significant. The next question asks the 5,005 individuals in the WJP survey who say they have been abused whether they have reported this police abuse. Here we find a sharply higher and statistically significant probability of reporting (compared with the 47-percentage-point world mean) among college and high school graduates. Compared with respondents with less than a high school education, college graduates are 8.0 percentage points more likely and high school graduates are 3.1 percentage points more likely to report abuse, although this estimate is not statistically significant. The data on reporting government misconduct from the WJP suggest that education is associated with a sharply higher probability of complaining.

The remaining four questions in Table 2 deal with reporting crime. The more educated are more likely to experience break-ins and armed robberies than the less educated and are much more likely to report the crime. Relative to the worldwide mean of 61 percent of reporting break-ins, college graduates were 10.2 percentage points more likely to report the crime, and high school graduates were 5.2 percentage points more likely to report the crime than those without a high school degree. Relative to the worldwide mean of 60 percent of reporting armed robberies, college graduates were 8.8 percentage points more likely to report the crime, but high school graduates were no more likely to report than those without a high school degree. The effect of education, particularly college education, on reporting crime is huge. In order to check the robustness of our findings, we revisit our analysis using logistic regressions and obtain almost identical results (available in online Appendix C). Taken together, the results in Table 2 are supportive of the central assumption of our theory, namely, that education encourages complaints about misconduct.

We investigate next whether a higher expected probability of success in a country encourages people to complain. In Table 3, we replace country fixed effects with two country-level controls (log of gross national income (GNI) per capita and rule of law) and with country-average assessments of the probability that a policeman violating the law will be punished. The last variable ranges from 0 to 1 . We have these data for only 56 countries. The data show large effects of the estimated probability of punishment on the likelihood of complaining, with parameter estimates ranging from .38 for complaints about government services to .9 for reporting police abuse. These high coefficients might be partially explained by the omission of country fixed effects, so the probability 
Table 3

Complaints and Education, with Controls for the Probability of Punishing Misconduct: World Justice Project (WJP)

\begin{tabular}{|c|c|c|c|c|c|c|c|}
\hline & $\begin{array}{c}\text { Complained } \\
\text { about } \\
\text { Government } \\
\text { Services }\end{array}$ & $\begin{array}{l}\text { Police } \\
\text { Abuse }\end{array}$ & $\begin{array}{l}\text { Report } \\
\text { Police } \\
\text { Abuse }\end{array}$ & $\begin{array}{c}\text { Burglary } \\
\text { (WJP) }\end{array}$ & $\begin{array}{c}\text { Report } \\
\text { Burglary } \\
\text { (WJP) }\end{array}$ & Assault & $\begin{array}{l}\text { Report } \\
\text { Assault }\end{array}$ \\
\hline College (WJP) & $\begin{array}{l}.081^{\star *} \\
(.021)\end{array}$ & $\begin{array}{c}-.009 \\
(.012)\end{array}$ & $\begin{array}{l}.121^{*} \\
(.046)\end{array}$ & $\begin{array}{c}.010 \\
(.015)\end{array}$ & $\begin{array}{l}.181^{* *} \\
(.031)\end{array}$ & $\begin{array}{c}-.005 \\
(.013)\end{array}$ & $\begin{array}{l}.112^{\star *} \\
(.032)\end{array}$ \\
\hline High/Middle School (WJP) & $\begin{array}{l}.036^{+} \\
(.019)\end{array}$ & $\begin{array}{c}-.016 \\
(.010)\end{array}$ & $\begin{array}{c}.065 \\
(.048)\end{array}$ & $\begin{array}{c}-.010 \\
(.014)\end{array}$ & $\begin{array}{l}.114^{* *} \\
(.030)\end{array}$ & $\begin{array}{c}-.007 \\
(.011)\end{array}$ & $\begin{array}{c}.021 \\
(.026)\end{array}$ \\
\hline Punishment for Police Misconduct & $\begin{array}{l}.385^{+} \\
(.225)\end{array}$ & $\begin{array}{l}.176 \\
(.111)\end{array}$ & $\begin{array}{l}.907^{\star *} \\
(.285)\end{array}$ & $\begin{array}{l}.102 \\
(.134)\end{array}$ & $\begin{array}{l}.654^{+} \\
(.340)\end{array}$ & $\begin{array}{l}.043 \\
(.158)\end{array}$ & $\begin{array}{l}.555^{\star} \\
(.232)\end{array}$ \\
\hline Log GNI per Capita & $\begin{array}{c}-.011 \\
(.019)\end{array}$ & $\begin{array}{r}-.017 \\
(.010)\end{array}$ & $\begin{array}{c}-.059^{* *} \\
(.019)\end{array}$ & $\begin{array}{c}-.031^{* *} \\
(.010)\end{array}$ & $\begin{array}{c}-.019 \\
(.026)\end{array}$ & $\begin{array}{l}.004 \\
(.012)\end{array}$ & $\begin{array}{c}-.076^{\star *} \\
(.017)\end{array}$ \\
\hline WJP Rule of Law Index & $\begin{array}{c}-.076 \\
(.109)\end{array}$ & $\begin{array}{c}-.009 \\
(.056)\end{array}$ & $\begin{array}{l}.321 \\
(.264)\end{array}$ & $\begin{array}{l}.173^{+} \\
(.101)\end{array}$ & $\begin{array}{c}.371 \\
(.278)\end{array}$ & $\begin{array}{r}-.229^{+} \\
(.125)\end{array}$ & $\begin{array}{l}.829^{* *} \\
(.231)\end{array}$ \\
\hline Constant & $\begin{array}{l}.053 \\
(.090)\end{array}$ & $\begin{array}{l}.128^{\star} \\
(.051)\end{array}$ & $\begin{array}{l}.246^{+} \\
(.133)\end{array}$ & $\begin{array}{l}.261^{\star *} \\
(.056)\end{array}$ & $\begin{array}{l}.107 \\
(.143)\end{array}$ & $\begin{array}{l}.145^{\star} \\
(.060)\end{array}$ & $\begin{array}{l}.463^{* *} \\
(.127)\end{array}$ \\
\hline$N$ & 53,738 & 54,763 & 2,974 & 54,847 & 7,792 & 54,823 & 3,787 \\
\hline$R^{2}$ & .012 & .012 & .044 & .010 & .042 & .008 & .071 \\
\hline Mean dependent variable & .160 & .055 & .476 & .143 & .597 & .069 & .582 \\
\hline
\end{tabular}

Note. Values are the results of ordinary least squares regressions of the dependent variable from the WJP data set on indicator variables for the education status of the respondents, a city average of the country score of the perceived likelihood of punishment for police who violate the law, and two country-level controls. The perceived in parentheses.

$p<.1$.
$+p<.05$

${ }^{*} p<.05$.
${ }^{* *} p<.01$. 
picks up other aspects of the quality of government. For two out of four measures of complaining (about government services and reporting burglary), our measures of education remain statistically significant and of comparable magnitude to their values in Table 2. The assumption that the expectation of success when reporting misconduct encourages individuals to complain also finds support in the WJP data. In the remainder of the empirical analysis, we return to the country fixed-effects specifications to make sure we do not contaminate our findings on individual behavior with countrywide factors.

\subsection{Variation across Countries}

An interesting empirical question is whether the results in Table 2 vary by the level of education in a country. For instance, the benefits of a college education may be relatively small in "educated countries," where people are generally more empowered and know how to act against government misconduct. Table 4 looks at this issue by going back to a country fixed-effects specification, but it includes interactions between an individual respondent's level of education and the country-average level of education (or more formally, between the respondent's level of education and an indicator variable for whether the expected number of years of schooling in the country is greater than 14). The results show that the relationship between education and complaining holds in "uneducated countries" but not in educated countries. In countries with lower levels of educational attainment, college and high school graduates are much more likely to complain and to report police abuse and crime than those without a high school degree. For example, a person with a college education is 6.3 percentage points more likely (compared with a mean of 15.6) to complain about government services and 10.2 percentage points more likely (compared with a mean of 46.8 ) to report police abuse than a person without a high school degree. In contrast, all coefficients of the interaction terms are negative and most are statistically significant, which indicates that these findings do not hold for more educated countries. Joint hypothesis tests indicate that, in these countries, there is no effect of education on complaining about government services, reporting of police misconduct, or reporting of assault, although there is a positive and statistically significant effect of college education on reporting burglary incidents. These results are robust to using different specifications (see online Appendix D) as well as different measures of educational attainment (not reported). The evidence suggests that uneducated people in uneducated countries might indeed not know how to complain or may be fearful of the authorities. In educated countries, in contrast, the knowledge of how to address government misconduct is more widespread and there is less fear of reprisal. As a consequence, the relationship between education and complaints is not nearly as clear-cut in educated countries.

One of the key motivating facts for our paper is that the quality of government improves with education in both democracies and autocracies. Accordingly, we expect our mechanism to work in both. In Table 5 we present the results including 
Table 4

Complaints, Education, and the Educational Attainment in the Country: World Justice Project (WJP)

\begin{tabular}{|c|c|c|c|c|c|c|c|}
\hline & $\begin{array}{c}\text { Complained } \\
\text { about } \\
\text { Government } \\
\text { Services }\end{array}$ & $\begin{array}{l}\text { Police } \\
\text { Abuse }\end{array}$ & $\begin{array}{l}\text { Report } \\
\text { Police } \\
\text { Abuse }\end{array}$ & $\begin{array}{l}\text { Burglary } \\
\text { (WJP) }\end{array}$ & $\begin{array}{l}\text { Report } \\
\text { Burglary } \\
\text { (WJP) }\end{array}$ & Assault & $\begin{array}{l}\text { Report } \\
\text { Assault }\end{array}$ \\
\hline College (WJP) & $\begin{array}{l}.063^{\star *} \\
(.012)\end{array}$ & $\begin{array}{l}.004 \\
(.005)\end{array}$ & $\begin{array}{l}.102^{* *} \\
(.037)\end{array}$ & $\begin{array}{l}.036^{\star *} \\
(.008)\end{array}$ & $\begin{array}{l}.118^{* *} \\
(.022)\end{array}$ & $\begin{array}{l}.033^{\star *} \\
(.009)\end{array}$ & $\begin{array}{l}.100^{* *} \\
(.027)\end{array}$ \\
\hline High/Middle School (WJP) & $\begin{array}{l}.040^{* *} \\
(.010)\end{array}$ & $\begin{array}{c}-.001 \\
(.004)\end{array}$ & $\begin{array}{l}.064^{\star} \\
(.030)\end{array}$ & $\begin{array}{l}.015^{\star} \\
(.006)\end{array}$ & $\begin{array}{l}.052^{* *} \\
(.015)\end{array}$ & $\begin{array}{l}.020^{* *} \\
(.006)\end{array}$ & $\begin{array}{l}.01 \\
(.020)\end{array}$ \\
\hline College $(\mathrm{WJP}) \times$ Educated & $\begin{array}{r}-.046^{+} \\
(.024)\end{array}$ & $\begin{array}{c}-.034^{\star *} \\
(.010)\end{array}$ & $\begin{array}{r}-.128^{+} \\
(.067)\end{array}$ & $\begin{array}{r}-.034^{*} \\
(.015)\end{array}$ & $\begin{array}{r}-.047 \\
(.039)\end{array}$ & $\begin{array}{c}-.031 \\
(.019)\end{array}$ & $\begin{array}{c}-.038 \\
(.047)\end{array}$ \\
\hline High/Middle School $($ WJP $) \times$ Educated & $\begin{array}{r}-.047^{\star} \\
(.023)\end{array}$ & $\begin{array}{c}-.026^{\star *} \\
(.009)\end{array}$ & $\begin{array}{c}-.171^{* *} \\
(.063)\end{array}$ & $\begin{array}{r}-.026^{+} \\
(.014)\end{array}$ & $\begin{array}{c}-.006 \\
(.034)\end{array}$ & $\begin{array}{l}-.02 \\
(.017)\end{array}$ & $\begin{array}{c}-.002 \\
(.037)\end{array}$ \\
\hline$N$ & 60,634 & 86,528 & 5,005 & 86,678 & 11,663 & 61,812 & 4,090 \\
\hline$R^{2}$ & .108 & .074 & .144 & .057 & .176 & .102 & .159 \\
\hline Countries & 63 & 88 & 88 & 88 & 88 & 63 & 63 \\
\hline Mean dependent variable & .156 & .0603 & .468 & .136 & .611 & .0665 & .599 \\
\hline
\end{tabular}

Note. Values are the results of ordinary least squares regressions of the dependent variable from the WJP data set on indicator variables for the education status of the respondents and their interactions with an indicator variable coded one if the educational attainment in the country is greater than 14 years. All regressions include fixed effects for countries. Clustered standard errors are in parentheses.

${ }^{+} p<.1$.
${ }_{*} p<.05$.

${ }_{* *}^{*} p<.01$. 
Table 5

Complaints, Education, and Democracy: World Justice Project (WJP)

\begin{tabular}{|c|c|c|c|c|c|c|c|}
\hline & $\begin{array}{l}\text { Complained } \\
\text { about } \\
\text { Government } \\
\text { Services }\end{array}$ & $\begin{array}{l}\text { Police } \\
\text { Abuse }\end{array}$ & $\begin{array}{l}\text { Report } \\
\text { Police } \\
\text { Abuse }\end{array}$ & $\begin{array}{l}\text { Burglary } \\
\text { (WJP) }\end{array}$ & $\begin{array}{c}\text { Report } \\
\text { Burglary } \\
\text { (WJP) }\end{array}$ & Assault & $\begin{array}{l}\text { Report } \\
\text { Assault }\end{array}$ \\
\hline College (WJP) & $\begin{array}{l}.054^{* *} \\
(.013)\end{array}$ & $\begin{array}{c}-.008 \\
(.005)\end{array}$ & $\begin{array}{l}.078^{\star} \\
(.036)\end{array}$ & $\begin{array}{l}.021^{* *} \\
(.007)\end{array}$ & $\begin{array}{l}.096^{\star *} \\
(.021)\end{array}$ & $\begin{array}{l}.022^{\star} \\
(.010)\end{array}$ & $\begin{array}{l}.077^{\star} \\
(.029)\end{array}$ \\
\hline High/Middle School (WJP) & $\begin{array}{l}.030^{* *} \\
(.011)\end{array}$ & $\begin{array}{r}-.008^{+} \\
(.004)\end{array}$ & $\begin{array}{l}.038 \\
(.033)\end{array}$ & $\begin{array}{l}.003 \\
(.006)\end{array}$ & $\begin{array}{l}.052^{\star *} \\
(.017)\end{array}$ & $\begin{array}{l}.016^{\star} \\
(.008)\end{array}$ & $\begin{array}{l}.003 \\
(.025)\end{array}$ \\
\hline College $($ WJP $) \times$ Autocracy & $\begin{array}{r}-.007 \\
(.023)\end{array}$ & $\begin{array}{l}.003 \\
(.011)\end{array}$ & $\begin{array}{l}.035 \\
(.057)\end{array}$ & $\begin{array}{l}.02 \\
(.016)\end{array}$ & $\begin{array}{l}.043 \\
(.040)\end{array}$ & $\begin{array}{l}.003 \\
(.016)\end{array}$ & $\begin{array}{c}.033 \\
(.040)\end{array}$ \\
\hline High/Middle School $($ WJP $) \times$ Autocracy & $\begin{array}{c}-.009 \\
(.021)\end{array}$ & $\begin{array}{l}.006 \\
(.009)\end{array}$ & $\begin{array}{c}-.017 \\
(.059)\end{array}$ & $\begin{array}{l}.027^{\star} \\
(.013)\end{array}$ & $\begin{array}{l}.014 \\
(.026)\end{array}$ & $\begin{array}{l}.004 \\
(.013)\end{array}$ & $\begin{array}{c}.023 \\
(.029)\end{array}$ \\
\hline$N$ & 57,648 & 83,554 & 4,941 & 83,700 & 11,455 & 58,844 & 3,989 \\
\hline$R^{2}$ & .106 & .074 & .14 & .056 & .176 & .103 & .156 \\
\hline Countries & 60 & 85 & 85 & 85 & 85 & 60 & 60 \\
\hline Mean dependent variable & .161 & .062 & .472 & .138 & .609 & .068 & .597 \\
\hline
\end{tabular}

Note. Values are the results of ordinary least squares regressions of the dependent variable from the WJP data set on indicator variables for the education status of the respondents and their interactions with an indicator variable coded one if the polity2 score from the 2011 Polity IV data set is below 0. All regressions include fixed effects for countries. Clustered standard errors are in parentheses.

$$
\begin{aligned}
& { }^{+} p<.1 . \\
& { }^{*} p<.05 . \\
& { }^{*} p<.01 .
\end{aligned}
$$


interactions between education variables and autocracy scores. The coefficients on interactions are generally insignificant, which indicates that our results hold consistent in both autocracies and democracies for complaining about government services, reporting police abuse, and reporting crime. These results are robust to changes in the cutoff points used to define autocracy (see online Appendix D) and to using a continuous rather than a dummy variable (not reported). The fact that the results hold strongly in autocracies is important. Taken together with the relationships in Figures 5-8, this suggests that it might be not only the voting mechanism stressed by Hirschman and Verba but also the decentralized process of individuals complaining about government misconduct that serves to discipline government officials and improve accountability as countries develop.

\subsection{Is Education a Proxy for Something Else?}

An important question about our finding is whether education is a proxy for something else that may encourage complaining. The leading possibilities are trust or social capital, income, social status, and gender. More trusting people may be better educated but also have greater confidence that their complaints will be addressed fairly. Richer people may be better educated but also have greater resources to complain and perhaps greater sums to complain about. Individuals of higher socioeconomic status may be better educated but may also feel more empowered to complain. Men may be better educated and also more aggressive or optimistic about success if they complain. Fortunately, the WJP data contain some information on each of these matters, so the concerns can be addressed empirically.

Several of the respondent-level questions asked in the WJP surveys concern the level of trust in institutions, and we aggregate them into a trust index. We also have for each individual a measure of trust in others. Although the WJP data do not contain information about the exact income of the respondents, they have information on the quintile of the income distribution into which the respondent falls. ${ }^{4}$ The WJP data set also contains a series of questions related to social status, including 22 questions on whether the respondent has a certain asset, service, or utility service (for example, a car, a cell phone, a credit card, and so on) and a self-assessment of his or her socioeconomic status. These questions, however, are available only in the 2011 and 2012 waves of data. Finally, the WJP data contain information about the gender of the respondent.

We ran a large number of specifications that check whether the inclusion of these additional controls changes our results on education. Table 6 presents the results of our base specification with trust in public institutions, gender, and four indicator variables for whether the income of the respondent is in the second, third, fourth, or highest quintile of the country's income distribution,

\footnotetext{
${ }^{4}$ For a few countries, income is not listed by quintiles but by quartiles (two countries) or deciles (four countries). In those cases, we have adjusted the categories to match the rest of the countries.
} 
Table 6

Complaints and Education, Controlling for the Level of Trust in Public Institutions, the Income of the Respondent, and Gender: World Justice Project (WJP)

\begin{tabular}{|c|c|c|c|c|c|c|c|}
\hline & $\begin{array}{l}\text { Complained } \\
\text { about } \\
\text { Government } \\
\text { Services }\end{array}$ & $\begin{array}{l}\text { Police } \\
\text { Abuse }\end{array}$ & $\begin{array}{l}\text { Report } \\
\text { Police } \\
\text { Abuse }\end{array}$ & $\begin{array}{l}\text { Burglary } \\
\text { (WJP) }\end{array}$ & $\begin{array}{c}\text { Report } \\
\text { Burglary } \\
\text { (WJP) }\end{array}$ & Assault & $\begin{array}{l}\text { Report } \\
\text { Assault }\end{array}$ \\
\hline College (WJP) & $\begin{array}{l}.053^{* *} \\
(.010)\end{array}$ & $\begin{array}{r}-.010^{+} \\
(.006)\end{array}$ & $\begin{array}{c}.049 \\
(.041)\end{array}$ & $\begin{array}{l}.031^{* *} \\
(.009)\end{array}$ & $\begin{array}{l}.112^{* *} \\
(.028)\end{array}$ & $\begin{array}{c}.019^{*} \\
(.008)\end{array}$ & $\begin{array}{l}.053^{*} \\
(.023)\end{array}$ \\
\hline High/Middle School (WJP) & $\begin{array}{l}.029^{\star *} \\
(.010)\end{array}$ & $\begin{array}{r}-.010^{\star} \\
(.005)\end{array}$ & $\begin{array}{l}.047 \\
(.035)\end{array}$ & $\begin{array}{l}.012^{+} \\
.007)\end{array}$ & $\begin{array}{l}.075^{\star \star} \\
.021)\end{array}$ & $\begin{array}{l}.012^{*} \\
(.006)\end{array}$ & $\begin{array}{r}-.010 \\
(.025)\end{array}$ \\
\hline Trust Index & $\begin{array}{c}-.074^{\star *} \\
(.026)\end{array}$ & $\begin{array}{c}-.050^{\star *} \\
(.012)\end{array}$ & $\begin{array}{l}.116^{\star} \\
(.048)\end{array}$ & $\begin{array}{c}-.041^{* *} \\
(.011)\end{array}$ & $\begin{array}{l}.012 \\
(.032)\end{array}$ & $\begin{array}{r}-.023^{+} \\
(.012)\end{array}$ & $\begin{array}{l}.047 \\
(.053)\end{array}$ \\
\hline Second income quintile & $\begin{array}{c}-.003 \\
(.008)\end{array}$ & $\begin{array}{c}-.004 \\
(.005)\end{array}$ & $\begin{array}{l}.031 \\
(.036)\end{array}$ & $\begin{array}{c}-.005 \\
(.005)\end{array}$ & $\begin{array}{l}.005 \\
(.019)\end{array}$ & $\begin{array}{c}-.004 \\
(.004)\end{array}$ & $\begin{array}{l}.047^{+} \\
(.024)\end{array}$ \\
\hline Third income quintile & $\begin{array}{c}-.01 \\
(.012)\end{array}$ & $\begin{array}{c}-.002 \\
(.005)\end{array}$ & $\begin{array}{l}.019 \\
(.033)\end{array}$ & $\begin{array}{c}-.003 \\
(.006)\end{array}$ & $\begin{array}{l}.022 \\
(.021)\end{array}$ & $\begin{array}{l}.003 \\
(.005)\end{array}$ & $\begin{array}{l}.065^{\star} \\
(.026)\end{array}$ \\
\hline Fourth income quintile & $\begin{array}{l}.005 \\
(.011)\end{array}$ & $\begin{array}{c}-.002 \\
(.007)\end{array}$ & $\begin{array}{l}.021 \\
(.043)\end{array}$ & $\begin{array}{c}-.004 \\
(.007)\end{array}$ & $\begin{array}{l}.016 \\
(.021)\end{array}$ & $\begin{array}{l}.004 \\
(.006)\end{array}$ & $\begin{array}{l}.063^{*} \\
(.026)\end{array}$ \\
\hline Highest income quintile & $\begin{array}{l}.001 \\
(.011)\end{array}$ & $\begin{array}{l}.003 \\
(.006)\end{array}$ & $\begin{array}{l}.01 \\
(.051)\end{array}$ & $\begin{array}{l}.009 \\
(.010)\end{array}$ & $\begin{array}{l}.059^{\star} \\
(.023)\end{array}$ & $\begin{array}{l}.001 \\
(.005)\end{array}$ & $\begin{array}{c}-.01 \\
(.040)\end{array}$ \\
\hline Male & $\begin{array}{l}.021^{\star *} \\
(.005)\end{array}$ & $\begin{array}{l}.022^{* *} \\
(.003)\end{array}$ & $\begin{array}{c}-.029 \\
(.024)\end{array}$ & $\begin{array}{l}.008^{\star} \\
(.004)\end{array}$ & $\begin{array}{c}-.014 \\
(.012)\end{array}$ & $\begin{array}{l}.017^{* *} \\
(.003)\end{array}$ & $\begin{array}{c}-.02 \\
(.019)\end{array}$ \\
\hline$N$ & 52,272 & 53,053 & 2,911 & 53,111 & 7,335 & 53,117 & 3,540 \\
\hline$R^{2}$ & .115 & .082 & .170 & .064 & .168 & .105 & .165 \\
\hline Mean dependent variable & .159 & .056 & .504 & .139 & .613 & .067 & .606 \\
\hline
\end{tabular}

Note. Values are the results of ordinary least squares regressions of the dependent variables from the WJP data set on indicator variables for the education status of the respondents; an index ranging between 0 and 1 measuring the trust in public institutions (with 1 indicating more trust); an indicator variable for whether the respondent is a male; and indicator variables for whether the income of the respondent is in the second, third, fourth, or highest quintile of the country's income distribution (the omitted variable is the indicator for the lowest quintile). All regressions include fixed effects for countries. Clustered standard errors are in parentheses. $N=62$ countries.

${ }^{+} p<.1$.
${ }^{*} p<.05$.
${ }_{* *}^{*} p<.01$. 
all of which are included in the regression. ${ }^{5}$ The results in Table 6 do not offer much evidence that trust, income, or social status matter for complaining, while education coefficients remain both sizable and statistically significant (except for reporting police abuse). These results hold across a range of specifications, including some with a full set of indicator variables for the income group of respondents interacted with the country fixed effect (see online Appendix E). Education is not merely a proxy for trust, income, or social status in these data.

There is some evidence that men are more likely than women to complain about government services but not to report police abuse, burglary, or assault (although they are more likely to report having been victims). We also check the effect of including self-assessments of the socioeconomic status of respondents-alone and interacted with the country fixed effects-in place of their income group (see online Appendixes F and G). ${ }^{6}$ The effects of education remain large and significant. We obtain similar results when we use indicator variables for whether respondents have a certain asset or utility service (see online Appendix $\mathrm{H}$ ) or when we use individuals' levels of trust in others instead of trust in public institutions (see online Appendix I). Finally, we check whether religion influences the probability of complaining and found no evidence that it does.

Another concern is that the propensity to complain is shaped by access to the complaint technology, such as a cell phone or a computer, rather than by education per se. As reported in online Appendix $\mathrm{H}$, indeed, having a cell phone sharply raises the probability of reporting police abuse and burglary, although not of complaining about government generally. At the same time, having a cell phone does not have much of an effect on education coefficients (there is also no evidence of complementarities between education and cell phone ownership). We do not find that having a computer affects the probability of complaining or reporting a crime. The evidence suggests that cell phones do indeed facilitate reporting of police abuse and crime, but education is by no means a proxy for having a cell phone.

One final concern to mention is the possibility of a survey response bias because uneducated people might worry about survey administrators being connected with police and therefore might not admit that they reported police abuse. However, this concern applies only to police and not to general complaining about government services. The fact that we have consistent results across types of complaints undermines this concern. Moreover, the WJP has a 97 percent response rate to these questions, which suggests that respondents are not afraid. We cannot fully discount this concern, but we doubt that it fully explains our fairly consistent results.

\footnotetext{
${ }^{5}$ This regression includes 55 countries, as three of the wealth variables are not available for eight countries. We replicated the analysis excluding these variables and obtained results similar to those reported in Table 6.

${ }^{6}$ Self-assessment of socioeconomic status is coded between 1 and 10 and was measured by responses to the question "Imagine a staircase with 10 steps, in which on the first step are located the poorest and on the 10th step, the richest. Where would you put yourself on this staircase?"
} 
The bottom line of this section is that education does not seem to be a proxy for income, trust, socioeconomic status, gender, or access to reporting technology. Education matters a great deal more than other determinants of complaints, and their inclusion in the regression does not substantially influence the impact of the education variables.

\section{Other Data Sources}

We next examine the robustness of our results in other data sources and probe the reasons for reporting or not reporting government misconduct and crime. In Table 7, we use the ICVS data on crime, which contain information on crime victimization, bribing, and reporting to the police and which have been used by several authors including Soares (2004a, 2004b), Van Dijk (2007), and Mocan (2008). We focus on the latest available survey for each country. Table 7 reports, for a sample of 125,000 observations from 71 countries, that the incidence of reporting burglary, attempted burglary, robbery, consumer fraud, and theft was sharply higher for better-educated individuals. Across specifications, the results confirm the findings in the WJP data.

Table 8 focuses on ICVS data on corruption and the reasons for reporting or not reporting requests for bribes. The first column shows, not surprisingly, that better-educated people are more likely to be asked for a bribe. The next two columns show that educated people are not more likely to report the request for a bribe to the police but are more likely to report it to a public or private agency. In explaining the reasons for not reporting, educated people are less likely to report that the matter was inappropriate for police, but they are also less likely to worry that the police will not do anything or to fear and/or dislike police. There is evidence here that the less educated are more concerned with police reprisals and hence fail to use their voice. In Table 9, we examine affirmative reasons in ICVS for reporting corruption but do not find any interesting and statistically significant effects.

Table 10 deals with the data from the Global Corruption Barometer 2009 produced by Transparency International. The sample consists of over 60,000 people from 62 countries. As in the ICVS data, educated people report much higher probabilities of being asked for a bribe: 4.3 percentage points higher for a college graduate than for a person with no high school education (compared with a mean of 17.7 percent). There is also strong evidence of college graduates being more likely to file a formal complaint for being asked to pay a bribe: with a worldwide average probability of a complaint of 19.8 percent, college graduates are 2.4 percentage points more likely to file a complaint. With respect to reasons for not reporting corruption requests, the evidence here is again considerably stronger than in the ICVS data. College graduates were 6.1 percentage points less likely than individuals without a high school education to report that they did not know how to file a complaint as the reason for not doing so (compared 
Table 7

Crime Victimization and Reporting: International Crime Victims Survey (ICVS)

\begin{tabular}{|c|c|c|c|c|c|c|c|c|c|c|}
\hline & $\begin{array}{c}\text { Burglary } \\
\text { (ICVS) }\end{array}$ & $\begin{array}{c}\text { Report } \\
\text { Burglary } \\
\text { (ICVS) }\end{array}$ & Attempt & $\begin{array}{c}\text { Report } \\
\text { Attempt }\end{array}$ & Robbery & $\begin{array}{l}\text { Report } \\
\text { Robbery }\end{array}$ & Fraud & $\begin{array}{c}\text { Report } \\
\text { Fraud }\end{array}$ & Theft & $\begin{array}{l}\text { Report } \\
\text { Theft }\end{array}$ \\
\hline College (ICVS) & $\begin{array}{l}.021^{\star \star} \\
(.003)\end{array}$ & $\begin{array}{l}.105^{\star *} \\
(.011)\end{array}$ & $\begin{array}{l}.034^{* *} \\
(.003)\end{array}$ & $\begin{array}{l}.044^{* *} \\
(.012)\end{array}$ & $\begin{array}{l}.023^{* *} \\
(.002)\end{array}$ & $\begin{array}{l}.091^{* *} \\
(.016)\end{array}$ & $\begin{array}{l}.104^{\star *} \\
(.003)\end{array}$ & $\begin{array}{l}.012^{\star *} \\
(.005)\end{array}$ & $\begin{array}{l}.084^{* *} \\
(.003)\end{array}$ & $\begin{array}{c}.036^{* \star} \\
(.009)\end{array}$ \\
\hline High/Middle School (ICVS) & $\begin{array}{l}.011^{\star *} \\
(.002)\end{array}$ & $\begin{array}{l}.056^{* *} \\
(.010)\end{array}$ & $\begin{array}{l}.028^{* *} \\
(.002)\end{array}$ & $\begin{array}{c}.024^{\star} \\
(.010)\end{array}$ & $\begin{array}{l}.019^{* *} \\
(.002)\end{array}$ & $\begin{array}{c}.029^{\star} \\
(.013)\end{array}$ & $\begin{array}{l}.052^{\star *} \\
(.003)\end{array}$ & $\begin{array}{l}.014^{\star *} \\
(.004)\end{array}$ & $\begin{array}{l}.044^{* *} \\
(.003)\end{array}$ & $\begin{array}{c}.014^{+} \\
(.007)\end{array}$ \\
\hline $\mathrm{N}$ & 126,318 & 15,289 & 125,596 & 13,382 & 126,367 & 8,546 & 115,860 & 24,906 & 126,162 & 24,475 \\
\hline$R^{2}$ & 0 & .006 & .001 & .001 & .001 & .004 & .008 & 0 & .005 & .001 \\
\hline Mean dependent variable & .128 & .571 & .114 & .305 & .0782 & .356 & .218 & .0505 & .206 & .276 \\
\hline Countries & 71 & 71 & 71 & 71 & 71 & 71 & 69 & 67 & 71 & 71 \\
\hline
\end{tabular}

Note. Values are the results of ordinary least squares regressions of the dependent variable from the ICVS data set on indicator variables for the education status of the respondents. All regressions include fixed effects for countries. Clustered standard errors are in parentheses.

$\begin{aligned} & + \\ & * \\ & *\end{aligned}<.1 .05$.

$\begin{array}{rl}* & p<.05 . \\ * * & p<.01\end{array}$ 
Table 8

Corruption Victimization and Reporting: International Crime Victims Survey

\begin{tabular}{|c|c|c|c|c|c|c|c|c|c|c|c|c|c|c|}
\hline & \multirow[b]{2}{*}{$\begin{array}{l}\text { Corruption } \\
\text { (ICVS) }\end{array}$} & \multirow[b]{2}{*}{$\begin{array}{c}\text { Report } \\
\text { Corruption } \\
\text { Police } \\
\text { (ICVS) }\end{array}$} & \multirow[b]{2}{*}{$\begin{array}{l}\text { Report } \\
\text { Corruption } \\
\text { Other } \\
\text { (ICVS) }\end{array}$} & \multicolumn{11}{|c|}{ If Not, Why Didn’t You Report It? } \\
\hline & & & & $\begin{array}{l}\text { Not } \\
\text { Serious } \\
\text { Enough }\end{array}$ & $\begin{array}{l}\text { Solved It } \\
\text { Myself }\end{array}$ & $\begin{array}{l}\text { Inappropriate } \\
\text { for Police }\end{array}$ & $\begin{array}{c}\text { Other } \\
\text { Authorities }\end{array}$ & $\begin{array}{c}\text { My } \\
\text { Family } \\
\text { Solved It }\end{array}$ & $\begin{array}{c}\text { No } \\
\text { Insurance }\end{array}$ & $\begin{array}{c}\text { Police } \\
\text { Could } \\
\text { Do } \\
\text { Nothing }\end{array}$ & $\begin{array}{c}\text { Police } \\
\text { Won't } \\
\text { Do } \\
\text { Anything }\end{array}$ & $\begin{array}{l}\text { Fear/Dislike } \\
\text { of Police }\end{array}$ & $\begin{array}{c}\text { Did } \\
\text { Not Dare }\end{array}$ & $\begin{array}{c}\text { Other } \\
\text { Reasons }\end{array}$ \\
\hline College (ICVS) & $\begin{array}{l}.096^{* *} \\
(005)\end{array}$ & $\begin{array}{l}.007 \\
.007)\end{array}$ & $\begin{array}{l}.011^{*} \\
(005)\end{array}$ & $\begin{array}{r}.038^{+} \\
(022)\end{array}$ & $\begin{array}{l}-.025 \\
(019)\end{array}$ & $\begin{array}{l}-.030^{*} \\
(015)\end{array}$ & $\begin{array}{l}-.005 \\
(019)\end{array}$ & $\begin{array}{l}-.004 \\
(010)\end{array}$ & $\begin{array}{l}.025 \\
(017)\end{array}$ & $\begin{array}{l}-.004 \\
(014)\end{array}$ & $\begin{array}{r}-.014^{+} \\
(007)\end{array}$ & $\begin{array}{r}-.023^{*} \\
(011)\end{array}$ & $\begin{array}{l}.01 \\
(013)\end{array}$ & $\begin{array}{l}.037^{* *} \\
(012)\end{array}$ \\
\hline High/Middle School (ICVS) & $\begin{array}{l}.058^{* *} \\
(.004)\end{array}$ & $\begin{array}{c}-.002 \\
(.006)\end{array}$ & $\begin{array}{l}.002 \\
(.005)\end{array}$ & $\begin{array}{l}.028 \\
(.019)\end{array}$ & $\begin{array}{c}-.013 \\
(.016)\end{array}$ & $\begin{array}{r}-.014 \\
(.013)\end{array}$ & $\begin{array}{c}-.014 \\
(.016)\end{array}$ & $\begin{array}{c}-.008 \\
(.008)\end{array}$ & $\begin{array}{l}.013 \\
(.015)\end{array}$ & $\begin{array}{l}.011 \\
(.012)\end{array}$ & $\begin{array}{r}-.006 \\
(.006)\end{array}$ & $\begin{array}{c}-.003 \\
(.009)\end{array}$ & $\begin{array}{r}-.006 \\
(.011)\end{array}$ & $\begin{array}{l}.012 \\
(.010)\end{array}$ \\
\hline$N$ & 46,022 & 5,324 & 4,432 & 5,239 & 5,231 & 5,082 & 5,221 & 5,082 & 5,082 & 5,082 & 5,233 & 5,221 & 5,082 & 5,260 \\
\hline$R^{2}$ & .01 & .001 & .001 & .001 & 0 & .001 & 0 & 0 & 0 & .001 & .001 & . 001 & . 001 & .002 \\
\hline endent $\mathrm{v}$ & .118 & . 0195 & .0111 & .344 & .215 & .112 & .208 & .046 & .16 & .0927 & .0294 & .0575 & .0803 & .0741 \\
\hline Countries & 23 & 23 & 22 & 23 & 23 & 22 & 23 & 22 & 22 & 22 & 23 & 23 & 22 & 23 \\
\hline
\end{tabular}

Note. Values are the results of ordinary least squares regressions of the dependent variable from the ICVS data set on indicator variables for the education status of the respondents. All regressions include fixed effects for countries. Clustered standard errors are in parentheses.

${ }_{*}^{+} p<.1$.

${ }^{*} p<.05$.
${ }^{*} p<.01$ 
Table 9

Reasons Corruption Was Reported: International Crime Victims Survey (ICVS)

\begin{tabular}{|c|c|c|c|c|c|c|c|c|}
\hline & $\begin{array}{l}\text { Recover } \\
\text { Property }\end{array}$ & $\begin{array}{l}\text { Insurance } \\
\text { Reasons }\end{array}$ & $\begin{array}{l}\text { Should Be } \\
\text { Reported }\end{array}$ & $\begin{array}{l}\text { Want Offender } \\
\text { Caught }\end{array}$ & To Stop It & To Get Help & Compensation & Other Reasons \\
\hline College (ICVS) & $\begin{array}{r}-.277^{+} \\
(.159)\end{array}$ & $\begin{array}{c}-.097 \\
(.170)\end{array}$ & $\begin{array}{c}-.044 \\
(.147)\end{array}$ & $\begin{array}{c}.207 \\
(.184)\end{array}$ & $\begin{array}{c}-.038 \\
(.142)\end{array}$ & $\begin{array}{c}.045 \\
(.103)\end{array}$ & $\begin{array}{c}-.045 \\
(.061)\end{array}$ & $\begin{array}{c}.152^{+} \\
(.079)\end{array}$ \\
\hline High/Middle School (ICVS) & $\begin{array}{c}-.094 \\
(.132)\end{array}$ & $\begin{array}{c}-.06 \\
(.135)\end{array}$ & $\begin{array}{c}-.014 \\
(.122)\end{array}$ & $\begin{array}{l}.14 \\
(.154)\end{array}$ & $\begin{array}{c}.022 \\
(.119)\end{array}$ & $\begin{array}{l}.092 \\
(.086)\end{array}$ & $\begin{array}{c}-.025 \\
(.051)\end{array}$ & $\begin{array}{c}.057 \\
(.064)\end{array}$ \\
\hline$N$ & 105 & 86 & 110 & 107 & 108 & 106 & 105 & 82 \\
\hline$R^{2}$ & .044 & .005 & .001 & .016 & .005 & .017 & .007 & .058 \\
\hline Mean dependent variable & .343 & .291 & .236 & .364 & .222 & .0755 & .0286 & . 0366 \\
\hline Countries & 23 & 22 & 23 & 23 & 23 & 23 & 23 & 14 \\
\hline
\end{tabular}

Note. Values are the results of ordinary least squares regressions of the dependent variable from the ICVS data set on indicator variables for the education status of the respondents. All regressions include fixed effects for countries. Clustered standard errors are in parentheses. ${ }^{+} p<.1$ 
Table 10

Corruption Victimization and Reporting: Transparency International's Global Corruption Barometer

\begin{tabular}{|c|c|c|c|c|c|c|c|c|}
\hline & \multirow[b]{2}{*}{$\begin{array}{l}\text { Corruption } \\
\text { (Barometer) }\end{array}$} & \multirow[b]{2}{*}{$\begin{array}{c}\text { Report } \\
\text { Corruption } \\
\text { (Barometer) }\end{array}$} & \multicolumn{6}{|c|}{ Why Did You Not Present the Complaint? } \\
\hline & & & $\begin{array}{l}\text { Did Not Know } \\
\text { How to } \\
\text { Do It }\end{array}$ & $\begin{array}{l}\text { It Would Have } \\
\text { Taken Too } \\
\text { Much Time }\end{array}$ & $\begin{array}{l}\text { It Would Not } \\
\text { Have Helped } \\
\text { at All }\end{array}$ & $\begin{array}{l}\text { Tried but } \\
\text { Couldn't }\end{array}$ & $\begin{array}{l}\text { Fear of } \\
\text { Reprisals }\end{array}$ & $\begin{array}{c}\text { Other } \\
\text { Reasons }\end{array}$ \\
\hline 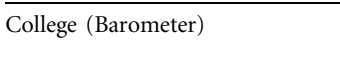 & $\begin{array}{l}.043^{* *} \\
(.004)\end{array}$ & $\begin{array}{l}.024^{*} \\
(.011)\end{array}$ & $\begin{array}{c}-.061^{\star *} \\
(.012)\end{array}$ & $\begin{array}{l}.006 \\
(.013)\end{array}$ & $\begin{array}{l}.072^{* *} \\
(.016)\end{array}$ & $\begin{array}{l}-.001 \\
(.008)\end{array}$ & $\begin{array}{r}-.032^{\star} \\
(.013)\end{array}$ & $\begin{array}{l}-.002 \\
(.008)\end{array}$ \\
\hline High/Middle School (Barometer) & $\begin{array}{l}.022^{* *} \\
(.004)\end{array}$ & $\begin{array}{l}.013 \\
(.010)\end{array}$ & $\begin{array}{c}-.015 \\
(.011)\end{array}$ & $\begin{array}{l}.005 \\
(.012)\end{array}$ & $\begin{array}{l}.049^{* *} \\
(.014)\end{array}$ & $\begin{array}{c}-.005 \\
(.007)\end{array}$ & $\begin{array}{c}-.030^{* *} \\
(.012)\end{array}$ & $\begin{array}{l}.003 \\
(.008)\end{array}$ \\
\hline$N$ & 60,184 & 10,179 & 8,160 & 8,160 & 8,160 & 8,160 & 8,160 & 8,160 \\
\hline$R^{2}$ & .00 & .00 & .00 & .00 & .00 & .00 & .00 & .00 \\
\hline Mean dependent variable & .177 & .198 & .163 & .24 & .494 & .0558 & .218 & .075 \\
\hline
\end{tabular}

Note. Values are the results of ordinary least squares regressions of the dependent variable from the Transparency International Global Corruption Barometer 2009 data set

on indicator variables for the education status of the respondents. All regressions include fixed effects for countries. Clustered standard errors are in parentheses. $N=62$ countries.

$$
\begin{aligned}
& { }^{*} p<.05 \text {. } \\
& { }_{*}^{*} p<.01 \text {. }
\end{aligned}
$$


with a mean of 16 percent). They are also more likely to report that it would not have helped. Last, they are 3.2 percentage points less likely to report a fear of reprisals (compared with a mean of 21.8 percent). The evidence points to a combination of the pure human capital story whereby the more educated know how to complain and a related story that these people do not fear the police. Evidence from the Global Corruption Barometer is broadly consistent with our basic theory.

$\mathrm{Xu}$ (2012) reexamines our hypotheses using the data set of complaints about provincial and local government officials in China using the China Public Governance Survey. He also finds that in the Chinese data, better-educated citizens are more likely to complain about both government misconduct and public services. Xu finds even larger effects of education than we do. He also finds that the reasons for higher numbers of complaints by the better educated include greater knowledge, greater civic-mindedness, and less fear of reprisals. Xu's evidence strongly reinforces our hypothesis that the complaint mechanism of institutional improvement is of particular importance in nondemocratic countries.

As a final step, we check whether countries with higher levels of education have lower rates of victimization of citizens by criminals and government officials. Figures 9-18 summarize these findings and confirm this basic aggregate prediction of the theory, namely, that countries with higher levels of education have lower rates of crime and better government performance. This particular prediction, of course is not new: it is the within-country mechanism that represents this paper's innovation.

\section{Conclusion}

We propose a new explanation of the universal positive association between a country's educational level and the quality of its government, namely, citizens' complaints. We argue that educated citizens complain more and that these complaints lead to better conduct by officials fearful of being punished, which in turn leads to greater accountability and a higher quality government. One attractive feature of this mechanism is that it is entirely decentralized and does not rely on any particular institution, such as democracy.

The evidence from newly collected data for 88 countries from the WJP surveys and from two additional sources shows that within countries better-educated citizens are indeed more likely to complain about both crime and government misconduct, such as corruption and police abuse. We show that the association between complaining and education is robust to the inclusion of other individual characteristics such as trust, socioeconomic status, or gender. We also show that country-average assessment of the probability that an official violating the law will be punished also influences the likelihood of complaints. Although our crosssectional evidence cannot establish causality, it points tentatively to human capital 


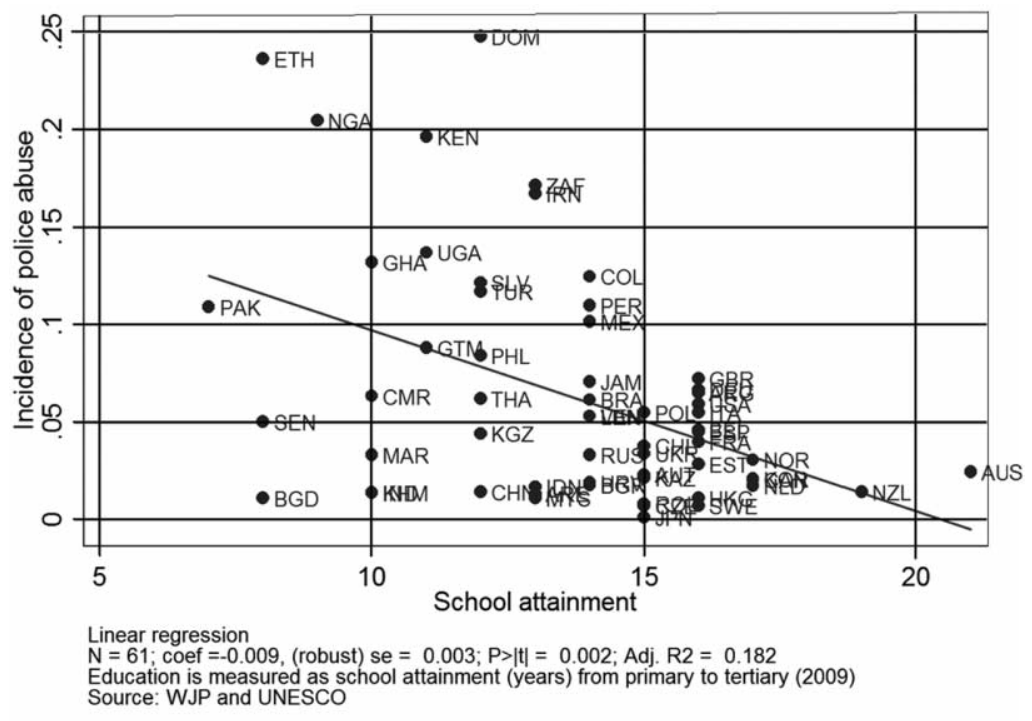

Figure 9. Police abuse and education: World Justice Project's General Population Surveys

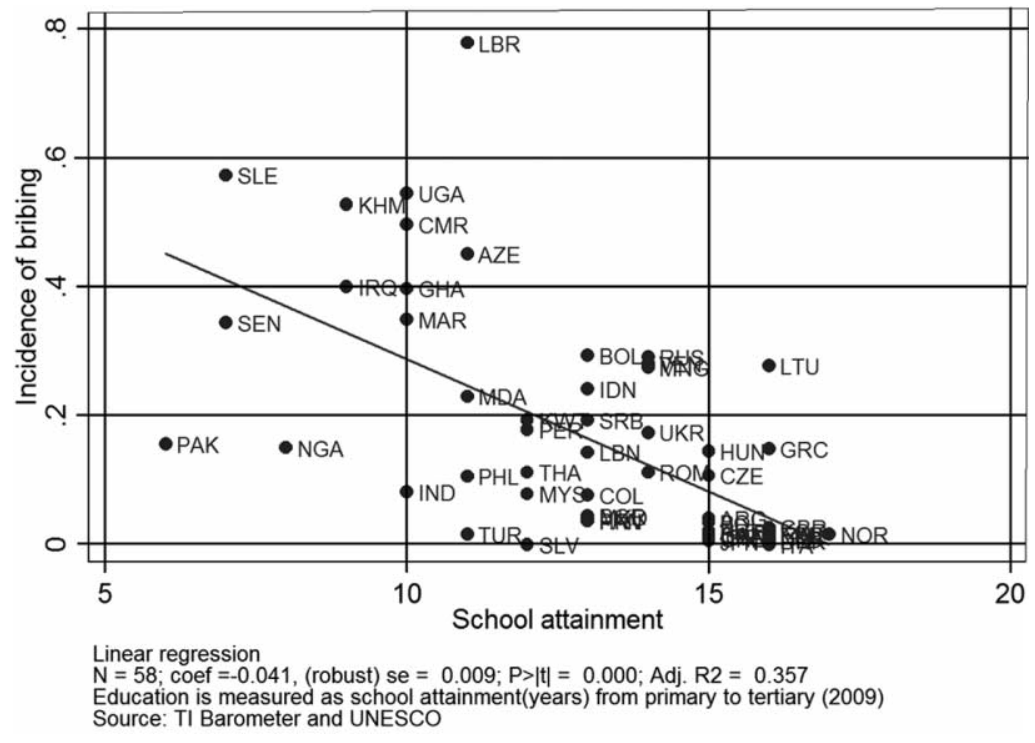

Figure 10. Bribery and education: Transparency International's Global Corruption Barometer 


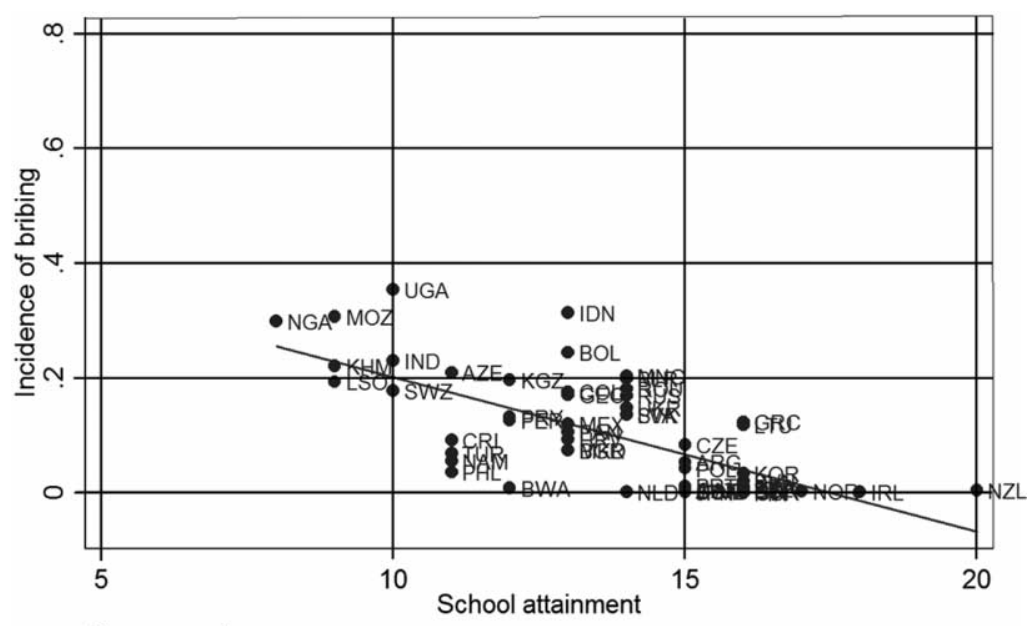

Linear regression

$N=61 ;$ coef $=-0.027$, (robust) $s e=0.004 ; P>|t|=0.000 ;$ Adj. $R 2=0.460$

Education is measured as school attainment(years) from primary to tertiary (2009)

Source: ICVS and UNESCO

Figure 11. Bribery and education: International Crime Victims Survey

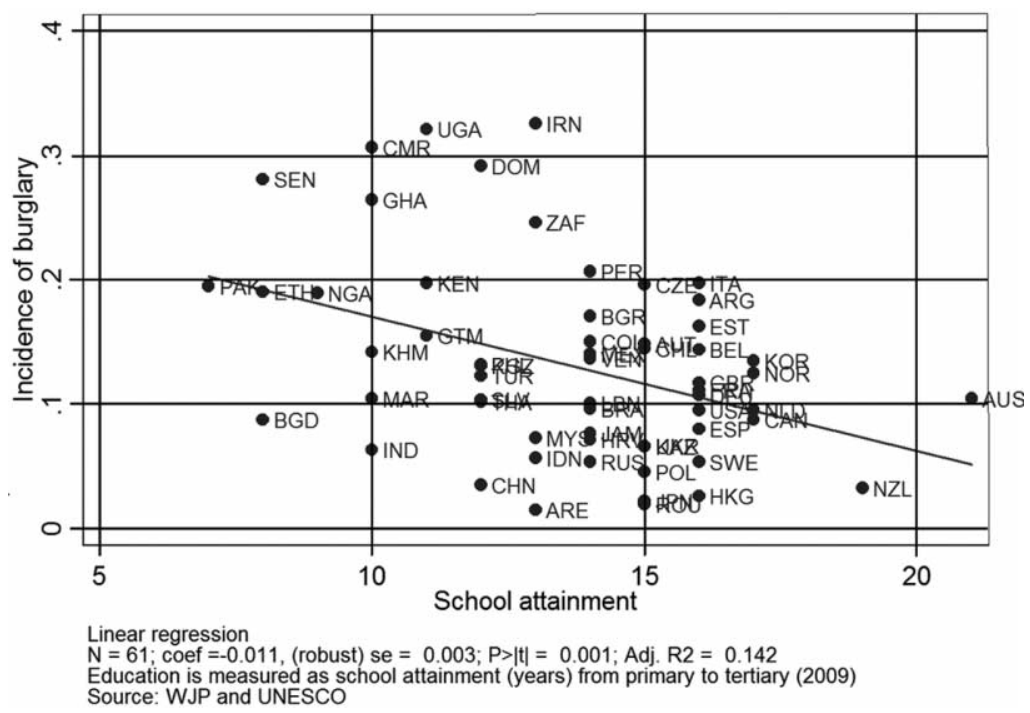

Figure 12. Burglary and education: World Justice Project's General Population Surveys 


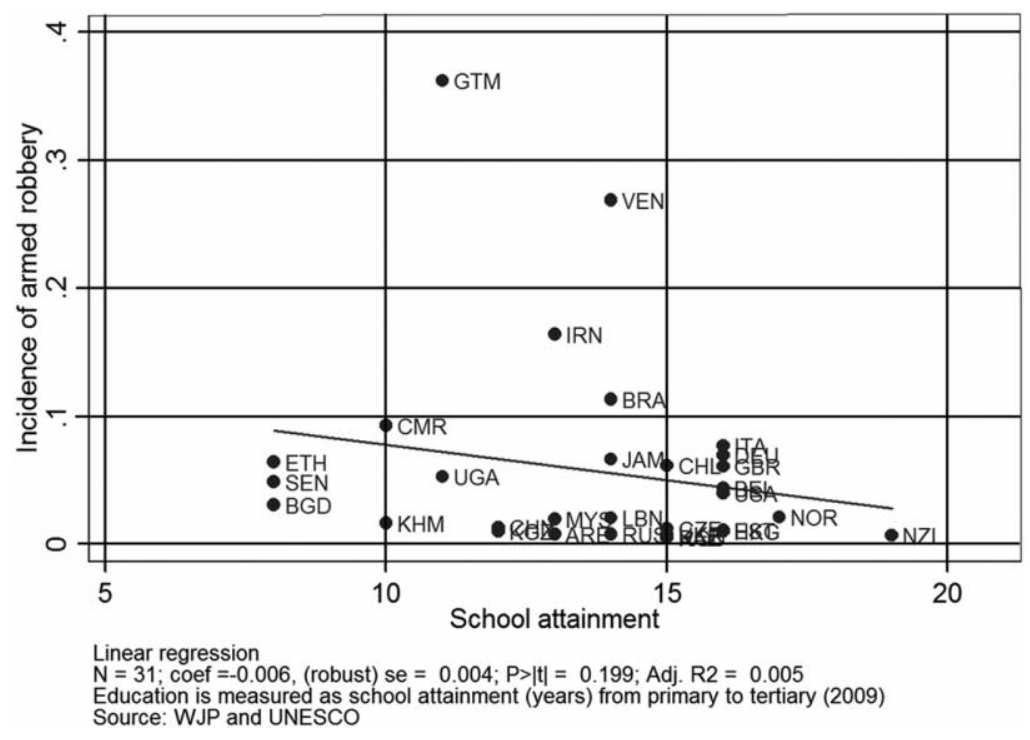

Figure 13. Armed robbery and education: World Justice Project's General Population Surveys

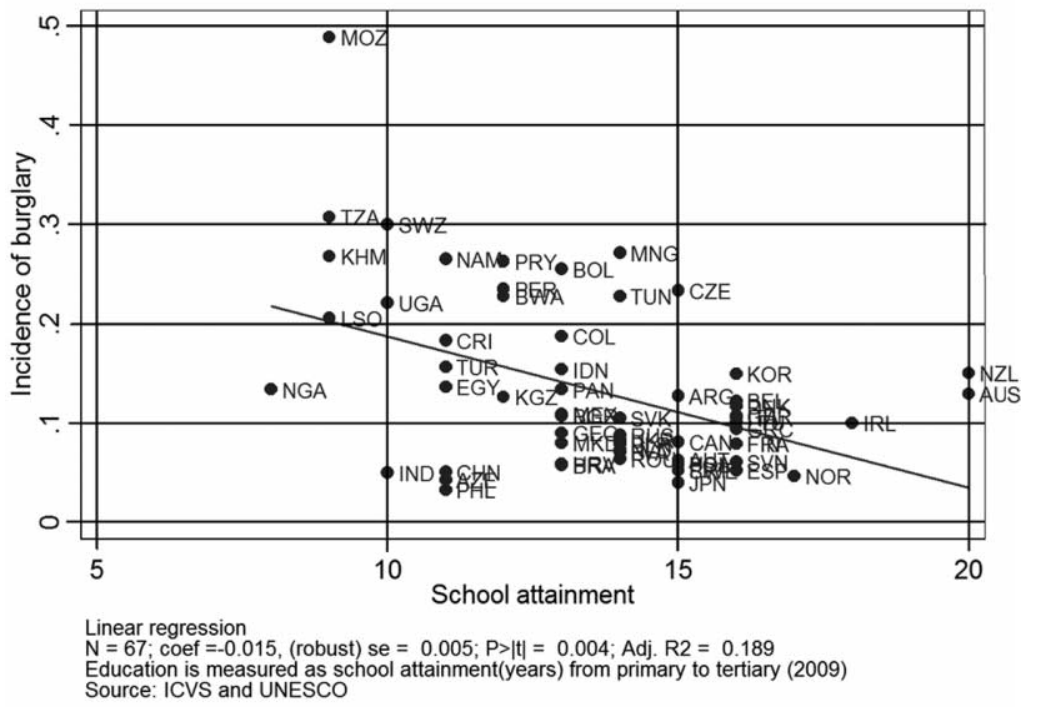

Figure 14. Burglary and education: International Crime Victims Survey 


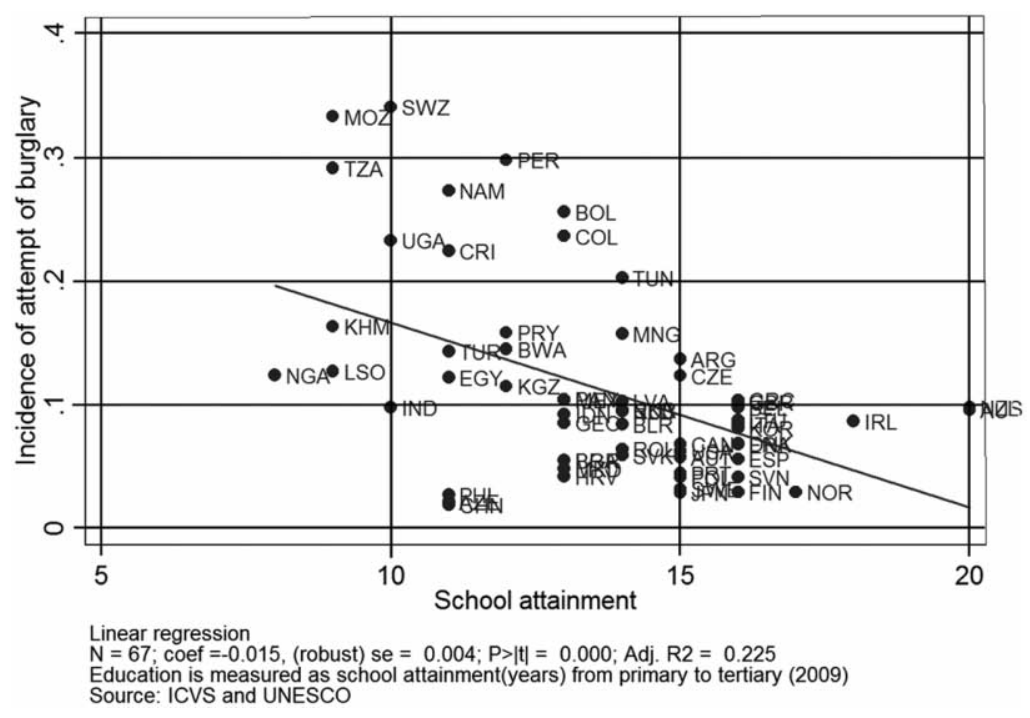

Figure 15. Attempted burglary and education: International Crime Victims Survey

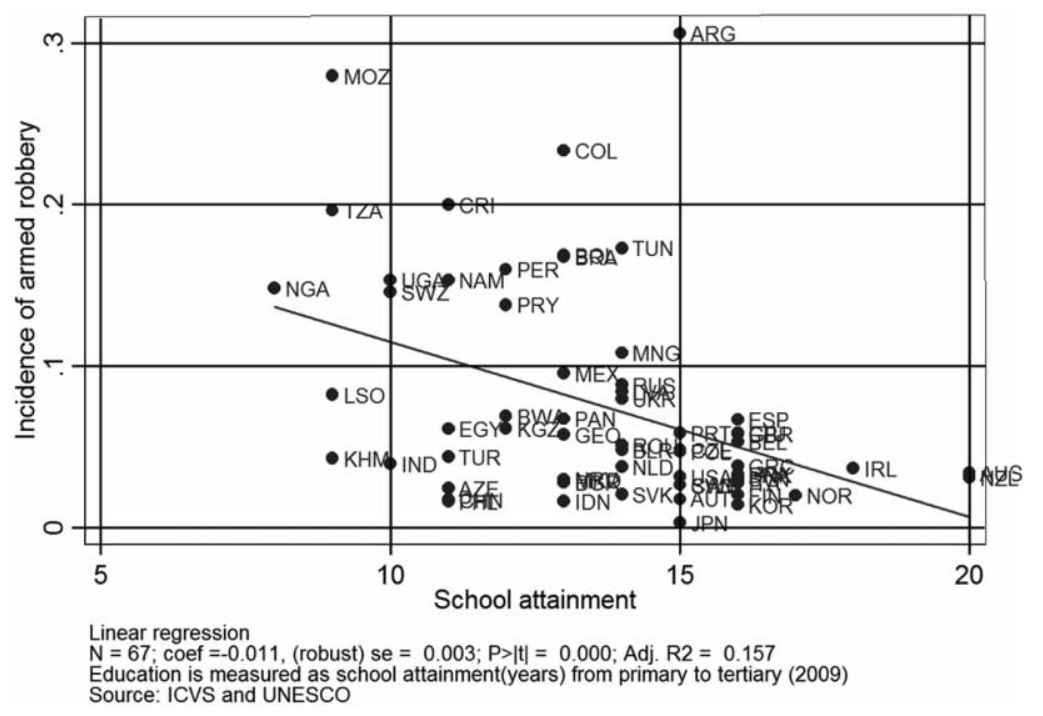

Figure 16. Armed robbery and education: International Crime Victims Survey 


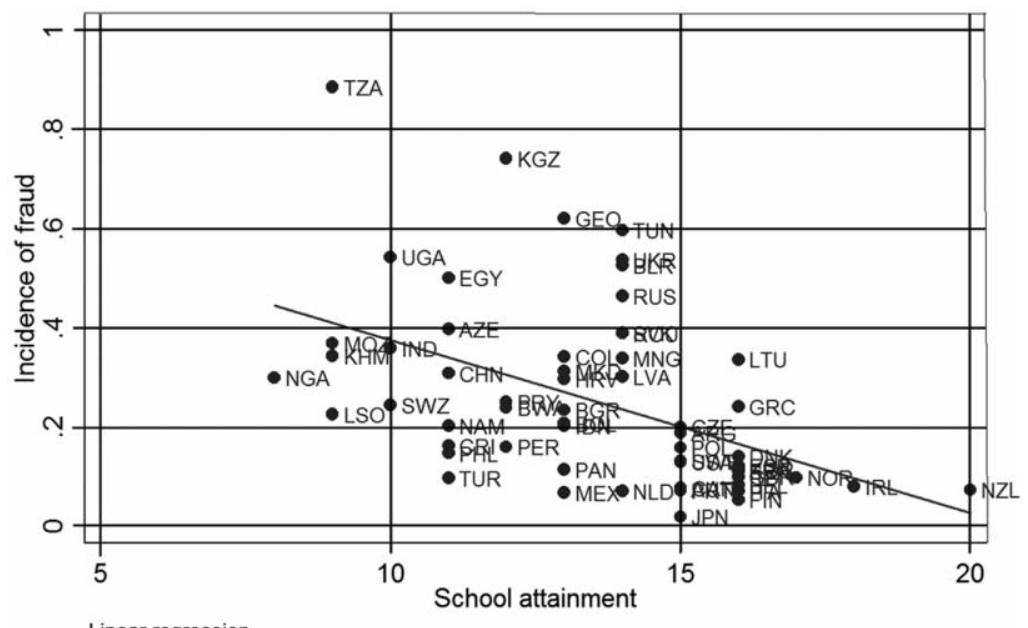

Linear regression

$\mathrm{N}=65 ;$ coef $=-0.035$, (robust) $\mathrm{se}=0.008 ; \mathrm{P}>|\mathrm{t}|=0.000 ;$ Adj. $\mathrm{R} 2=0.211$

Education is measured as school attainment(years) from primary to tertiary (2009)

Source: ICVS and UNESCO

Figure 17. Fraud and education: International Crime Victims Survey

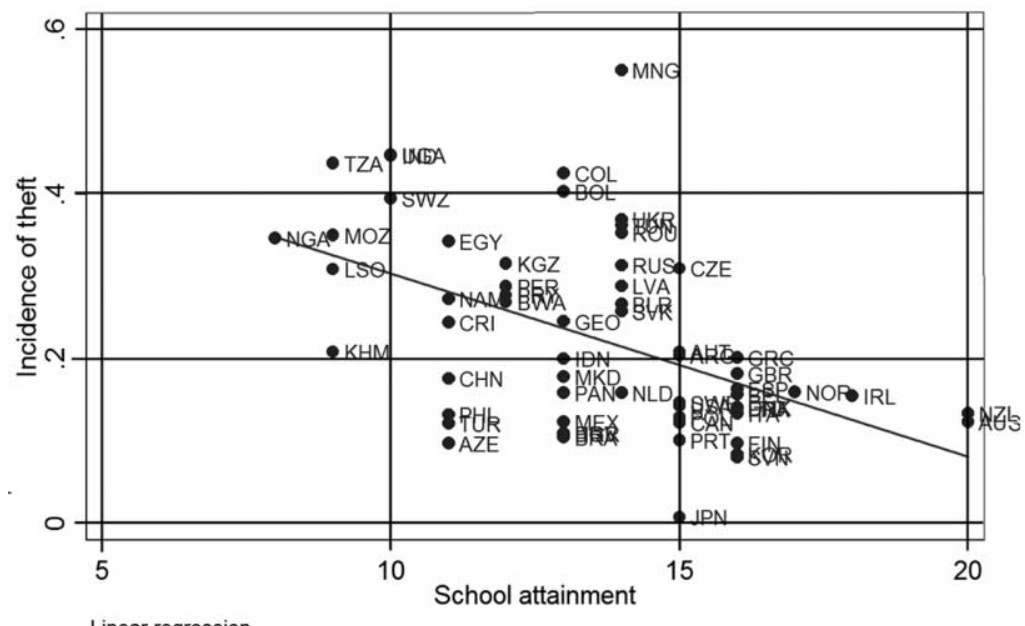

Linear regression

$\mathrm{N}=67 ;$ coef $=-0.022$, (robust) $\mathrm{se}=0.004 ; \mathrm{P}>|\mathrm{t}|=0.000 ;$ Adj. $\mathrm{R} 2=0.236$ Education is measured as school attainment(years) from primary to tertiary (2009) Source: ICVS and UNESCO

Figure 18. Theft and education: International Crime Victims Survey 
operating through complaints as an operative mechanism of accountability and institutional improvement.

\section{References}

Acemoglu, Daron, Simon Johnson, James A. Robinson, and Pierre Yared. 2005. From Education to Democracy? American Economic Review 95:44-49.

Agrast, Mark David, Juan Carlos Botero, Joel Martinez, Alejandro Ponce, and Christine Pratt. 2012. WJP Rule of Law Index 2012. Washington, D.C.: World Justice Project.

Algan, Yann, Pierre Cahuc, and Andrei Shleifer. 2013. Teaching Practices and Social Capital. American Economic Journal: Applied Economics 5(3):189-210.

Barro, Robert J. 1999. Determinants of Democracy. Journal of Political Economy 107:S158 S183.

Bobba, Matteo, and Decio Coviello. 2007. Weak Instruments and Weak Identification in Estimating the Effects of Education on Democracy. Economics Letters 96:301-6.

Botero, Juan C., and Alejandro Ponce. 2011. Measuring the Rule of Law. Working Paper No. 001. The World Justice Project, Washington, D.C.

Botero, Juan Carlos, Alejandro Ponce, and Andrei Shleifer. 2012. Education and the Quality of Government. Working Paper No. 18119. National Bureau of Economic Research, Cambridge, Mass.

Campbell, David E. 2006. Why We Vote: How Schools and Communities Shape Our Civic Life. Princeton, N.J.: Princeton University Press.

Castelló-Climent, Amparo. 2008. On the Distribution of Education and Democracy. Journal of Development Economics 87:179-90.

Dee, Thomas S. 2004. Are There Civic Returns to Education? Journal of Public Economics 88:1697-1720.

Dewey, John. 1944. Democracy and Education. New York: Free Press.

Di Tella, Rafael, Sebastian Edwards, and Ernesto Schargrodsky. 2010. The Economics of Crime: Lessons for and from Latin America. Chicago: University of Chicago Press.

Djankov, Simeon, Rafael La Porta, Florencio Lopez-de-Silanes, and Andrei Shleifer. 2010. Disclosure by Politicians. American Economic Journal: Applied Economics 2(1):179-209.

Ferraz, Claudio, and Frederico Finan. 2008. Exposing Corrupt Politicians: The Effects of Brazil's Publicly Released Audits on Electoral Outcomes. Quarterly Journal of Economics 123:703-45.

2011. Electoral Accountability and Corruption in Local Governments: Evidence from Audit Reports. American Economic Review 101:1274-1311.

Ferraz Claudio, Frederico Finan, and Diana B. Moreira. 2012. Corrupting Learning: Evidence from Missing Federal Education Funds in Brazil. Journal of Public Economics 96: 712-26.

Glaeser, Edward L., Rafael La Porta, Florencio Lopez-de-Silanes, and Andrei Shleifer. 2004. Do Institutions Cause Growth? Journal of Economic Growth 9:271-303.

Glaeser, Edward, Giacomo Ponzetto, and Andrei Shleifer. 2007. Why Does Democracy Need Education? Journal of Economic Growth 12:77-99.

Hayek, Friedrich A. 1960. The Constitution of Liberty. Chicago: University of Chicago Press.

Hirschman, Albert O. 1970. Exit, Voice, and Loyalty: Responses to Decline in Firms, Organizations, and States. Cambridge, Mass.: Harvard University Press. 
La Porta, Rafael, Florencio Lopez-de-Silanes, Andrei Shleifer, and Robert Vishny. 1999. The Quality of Government. Journal of Law, Economics, and Organization 15:222-79.

Milligan, Kevin, Enrico Moretti, and Philip Oreopoulus. 2004. Does Education Improve Citizenship? Evidence from the United States and the United Kingdom. Journal of Public Economics 88:1667-95.

Mocan, Naci. 2008. What Determines Corruption? International Evidence from Microdata. Economic Inquiry 46:493-510.

Murtin, Fabrice, and Romain Wacziarg. 2011. The Democratic Transition. Working Paper No. 17432. National Bureau of Economic Research, Cambridge, Mass.

Nie, Norman H., Jane Junn, and Kenneth Stehlik-Barry. 1996. Education and Democratic Citizenship in America. Chicago: University of Chicago Press.

Olken, Benjamin. 2007. Monitoring Corruption: Evidence from a Field Experiment in Indonesia. Journal of Political Economy 115:200-249.

Pande, Rohini. 2011. Can Informed Voters Enforce Better Governance? Experiments in Low-Income Democracies. Annual Review of Economics 3:215-37.

Pandey, Priyanka, Ashwini R. Sehgal, Michelle Riboud, David Levine, and Madhav Goyal. 2007. Informing Resource Poor Populations and the Delivery of Entitled Health and Social Services in Rural India. Journal of the American Medical Assocation 298:186775.

Putnam, Robert D. 1993. Making Democracy Work: Civil Traditions in Modern Italy. Princeton, N.J.: Princeton University Press.

Reinikka, Ritva, and Jakob Svensson. 2004. Local Capture: Evidence from a Central Government Transfer Program in Uganda. Quarterly Journal of Economics 119:679-705.

Reinikka, R., and J. Svensson. 2005. Fighting Corruption to Improve Schooling: Evidence from a Newspaper Campaign in Uganda. Journal of the European Economic Association $3(2-3): 1-9$.

Soares, Rodrigo R. 2004a. Crime Reporting as a Measure of Institutional Development. Economic Development and Cultural Change 52:851-71.

. 2004b. Development, Crime, and Punishment: Accounting for the International Differences in Crime Rates. Journal of Development Economics 73:155-84.

Svensson, Jakob. 2005. Eight Questions about Corruption. Journal of Economic Perspectives 19(3):19-42.

Treisman, Daniel. 2000. The Causes of Corruption: a Cross-National Study. Journal of Public Economics 76:399-457.

Van Dijk, Jan 2007. The World of Crime: Breaking the Silence on Problems of Security, Justice, and Development across the World. Thousand Oaks, Calif.: SAGE Publications.

Verba, Sidney, and Norman H. Nie. 1972. Participation in America: Political Democracy and Social Equality. Chicago: University of Chicago Press.

Verba, Sidney, Kay Lehman Schlozman, and Henry Brady. 1995. Voice and Equality: Civic Voluntarism in American Politics. Cambridge, Mass.: Harvard University Press.

Wolfinger, Raymond E., and Steven J. Rosenstone. 1980. Who Votes? New Haven, Conn.: Yale University Press.

Xu, Yiqing. 2012. Why Do More Educated People Complain More? Evidence from Chinese Provincial Capitals. Unpublished manuscript. Massachusetts Institute of Technology, Department of Political Science, Cambridge, Mass. 